\title{
Anatomy of Labrador Sea Heinrich layers
}

\author{
Reinhard Hesse*, Saeed Khodabakhsh ${ }^{1}$ \\ Department of Earth and Planetary Sciences, McGill University, Montreal, Que., H3A 2A7, \\ Canada.
}

Received; accepted

\begin{abstract}
Heinrich layers (H-layers) are distinct, decimetre to centimetre thick layers of ice-rafted debris (IRD) that were deposited in the North Atlantic during the Late and middle Pleistocene. H-layers (H-layers) are characterized by high detrital carbonate and low foraminifera contents. In the Labrador Sea, H-layers reach metre thickness in some proximal core sites near the iceberg source of the Hudson Strait ice stream and show five distinct depositional facies involving sediment lofting and low-density turbidity currents as sediment delivery processes besides ice rafting. Thick massive ice-rafted layers (type I H-layers) occur in the most proximal parts of H-layer3 and older H-layers. Within $300 \mathrm{~km}$ distance from the assumed Hudson Strait ice stream terminus, H-layers somewhat more distal than type I H-layers consist predominantly of stacked thin layers of graded muds containing IRD (type II H-layers). The graded muds that are spiked with IRD resulted from the deposition of fine-grained lofted sediment that collected dropstones and-grains under the iceberg route. At greater distance from the Hudson Strait outlet on the slope and rise south of the strait, $\mathrm{H}$ layers on the levees of tributary canyons to the Northwest Atlantic Mid-Ocean Channel (NAMOC) consist of alternations of thin mud turbidites with intercalated laminae of IRD (type III H-layers). On the levees of NAMOC, type IV H-layers consist of layers of IRD alternating with fewer finegrained spill-over turbidites, because the spill-over frequency from the deep channel was less than that from the less deep canyons on the slope. Type $\mathrm{V}$ is made up of bioturbated hemipelagic muds with coarser IRD and occurs in regions between canyons not reached by spill-over turbidity currents

$$
\text { PAGE \* ARABIC } 53
$$
\end{abstract}


and in distal regions of the open ocean or on seamounts. Transport of significant portions of the sediment in H-layers by suspended sediment columns lofted from sand-carrying fresh-water turbidity currents (type II) and by low-density turbidity currents (types III and IV) explains the high percentage of detrital carbonate in the fine $(<63 \mu \mathrm{m})$ grain-size fractions $(>80 \%$ of the total detrital carbonate of the bulk sediment), which cannot be derived from icebergs alone. It also explains the low magnetic susceptibility and low grey levels on the colour scale compared to H-layers in the North Atlantic east of Greenland. The anomalously great thickness of individual H-layers on the slope and rise off the Hudson Strait as documented in isopach maps reflects the combined effect of the various processes involved in their deposition. Four hypotheses for the origin of H-events are discussed - (i) the binge-purge model, (ii) the subglacial outburst-flow model, (iii) the external forcing model, and (iv) the catastrophic ice-shelf break-up model

Keywords: Heinrich layers, Labrador Sea, ice rafting, sediment lofting, turbidity currents, iceproximal environments.

\section{${ }^{1}$ 1. Introduction}

Heinrich events (H-events) are episodes of intensified iceberg-drift in the North Atlantic during which distinct, decimetre to centimetre thick layers of ice-rafted debris (IRD) were deposited that have been identified in Late Pleistocene deep-sea sediments (Heinrich, 1988; Bond et al,. 1992; Broecker et al., 1992). Six conventionally recognized H-events (H1 to H6) occurred during the last glaciation between 10 and $67 \mathrm{ka}$ (Fig. 1). H0 was identified as a Heinrich-like event on the SE Baffin Shelf (Andrews et al., 1995), and Rashid et al. (2003a) introduced an eighth event H5a

1 *Corresponding author. Also: Dept. of Geo- and Environmental Sciences, Sec. Geology, Ludwig Maximilians University Munich, Germany.

${ }^{.1}$ Present address: Department of Geology, Bu-Ali-Sina University, 65178 Hamedan, Iran 
between H5 and H6. Heinrich (1988) in his original work on episodic ice-rafting in the eastern North Atlantic identified 5 additional layers prior to the last glaciation extending the H-layer stratigraphy in time back into the penultimate glaciation at 130 ka.. Rasmussen et al. (2003) detected twelve H-layers in a core from the southeastern Labrador Sea off Newfoundland also dating back to $130 \mathrm{ka}$ at termination 2. Hiscott et al. (2001) using a core from the southwestern Labrador Sea extended the H-layer record back 340 ka to H-layer 13. Heinrich-like events can be traced back to $\sim 640$ ka during Marine Isotope Stage (MIS) 16 in the middle Pleistocene (Hodell et al., 2008; Naafs et al. 2011, 2013). Heinrich layers (H-layers) show specific characteristics compared to normal hemipelagic sediment with IRD, namely high magnetic susceptibility, high grey levels on the colouration scale, high concentrations of detrital carbonate, and low concentrations of foraminifera among which Neogloboquadrina pachyderma (sinistral) (Nps) is dominant (Fig. 2).

Labrador Sea Heinrich layers share with their distal equivalents in North Atlantic the (1) high concentration of lithic fragments dominated by detrital carbonate, although the carbonate concentration in the Labrador Sea is higher than in the North Atlantic ice-rafting belt, and the (2) low concentration of foraminifera with a high proportion of Nps. In contrast to their North Atlantic counterparts (3) magnetic susceptibility is low (Andrews and Tedesco, 1992) and (4) their coloration distinct with higher grey levels than the under- and overlying sediment (Fig. 3; Andrews et al. 1993; Grousset et al., 1993). The high magnetic susceptibility and grey level values of Heinrich layers (up to $2.5^{*} 10^{-4}$ e.m.u. and up to 260 , respectively,) in the North Atlantic are due to their high terrigenous content (Grousset et al. 1993). The low magnetic susceptibility $\left(7.7 * 10^{-5}\right.$ e.m.u) and gray levels (35-45) in the northwestern Labrador Sea, on the other hand, reflect the dilution of the ice-proximal H-layers by detrital carbonate both in the fine and coarse grain-size 
fractions (Andrews and Tedesco, 1992; Rashid et al., 2003b; Fig. 3). Heinrich layers also show distinct $\mathrm{Nd}$ and $\mathrm{Sr}$ isotopic signatures of their non-carbonate lithic grains and the fine-grained bulk sediment (Barber, 2001; Hemming 2004).

Among the few foraminifera specimen present, the percentage of Nps reaches a maximum during $\mathrm{H}$-events (Fig. 1), indicating that $\mathrm{H}$-events occurred when the climate was coldest. The highest percentages of $N p s$ in $\mathrm{H}$-layers occur simultaneously with the lowest $\delta^{18} \mathrm{O}$ values in Greenland ice (Fig. 3B); both are proxies for low temperatures, in surface-ocean water and air, respectively. Heinrich ice-rafting events thus coincided with minimum temperatures during Late Pleistocene climate fluctuations, whereas their middle Pleistocene precursors do not seem to be correlated with the minimum temperatures of the climatic cycles (Naafs, et al. 2011, 2013).

The detailed anatomy of ice-proximal Heinrich layers in the Labrador Sea is unravelled here for the first time based on the works of Khodabakhsh (1997), Hesse and Khodabakhsh $(1998,2006)$ and Rashid et al. (2003b). Common misconceptions in the paleoclimatic and paleoceanographic literature about the processes involved in the formation of ice-proximal H-layers in the Labrador Sea stem from the lack of information about the internal sedimentary structures of H-layers which can be obtained with the use of X-radiographs that are generally not acquired in routine paleoceanographic studies. Here we present the first detailed account of the structures, textures and geochemistry of Labrador Sea H-layers based on an X-radiography study of $1 \mathrm{~cm}$ thick sediment slabs sliced from the top of the core halves of 46 cores, together with grain-size analyses, oxygen and carbon isotopic analyses and organic-matter studies. Interpretation of the structural evidence elucidates a variety of auxiliary processes that contribute to the accumulation of thick proximal $\mathrm{H}$ layers. The structure and texture of H-layers in the Labrador Sea reveal a complex origin, involving, besides ice rafting, at least three additional sediment transport and delivery mechanisms: (i) 
sediment lofting from sand-rich turbidity currents, (ii) spillover of turbidity currents from the Northwest Atlantic Mid-Ocean Channel (NAMOC) and its tributaries, and (iii) turbid surface plumes (Hesse et al., 1997b; deGelleke et al., 2013) that generally are much more efficient sediment-transport processes than ice-rafting. Hesse and Khodabakhsh (2006) emphasized the significance of H-events as possibly constituting the main episodes for clastic sediment delivery to a small subpolar ocean basin like the Labrador Sea during glacial times.

\section{Heinrich events and rapid Pleistocene climate change}

H-events correlate with rapid Late Pleistocene climate changes coinciding with the coldest parts of Bond cooling cycles (Broecker, 1994) that were followed by abrupt warming (Fig. 1; Bond et al., 1993). On average Bond cycles span about 7000 years (Sarnthein et al., 2001). Superposed on the Bond cycles are shorter millenial-scale Dansgaard-Oeschger (D-O) oscillations lasting about 1500 years on average with shifts of the mean annual air temperature over the Greenland Ice Sheet of 5$10^{\circ} \mathrm{C}$ between the warm and cold parts of these oscillations. They have been detected in Greenland ice cores (Dansgaard et al., 1993) and are also asymmetric (slow cooling followed by rapid warming). The oldest H-like layers during MIS 16 do not show this asymmetry (Naafs et al. 2011, 2013). The relation of $\mathrm{H}$-events to climate fluctuations of the Bond cycles has been established by comparison of the Greenland ice-core record with the deep-sea sediment record using $\delta^{18} \mathrm{O}$ fluctuations and the abundance of the polar foraminifera $\mathrm{Nps}$ as well as AMS ${ }^{14} \mathrm{C}$ dating (Fig. 3, Bond et al. 1992, 1993, 1999; Broecker et al., 1992). Petrographic and isotopic provenance indicators (Hemming, 2004) and isopach maps of individual Heinrich layers (Figs. 4, 5) point to the Hudson Strait outlet of the Pleistocene Laurentide Ice Sheet (LIS) as major iceberg source for most H-events. However, the other northern hemisphere ice sheets on Greenland, the Barents Sea and Fennoscandia and ice caps on Iceland and the British Isles were also contributing IRD (Grousset et 
al., 1993; Stanford et al., 2011; Small et al., 2013). Andrews et al. (2012) investigated other local sources of IRD to H-layers 0-4 from Cumberland Sound and Baffin Island. The volume of iceberg discharge from the Hudson Strait ice stream (HSIS) during H-events must have been enormous in order to accumulate thick dropstone layers over wide areas of North Atlantic, because the average duration of individual events was short, $500 \pm 250$ years with estimates ranging from a few hundred to 2300 years (Hemming, 2004; Thomson et al., 1995), although recent work by Stanford et al. (2011) suggests that Heinrich Event 1 s.l. may have lasted as long as 4000 years. These estimates were based on sedimentation rates for the North Atlantic Heinrich layers, for which Broecker et al. (1992) used $6 \mathrm{~cm} / 10^{3}$ years obtaining estimated durations for events 1,2 and 3 of 1000, 500 and 1800 years, respectively. Using ${ }^{230} \mathrm{Th}_{\text {excess }}$ profiles, Thomson et al. (1995) estimated durations of 2000, 1120 and 710 years for the these same events, respectively. In the northwestern Labrador Sea the sedimentation rates of Heinrich layers were an order of magnitude higher than those of normal hemipelagic sediment, e.g. $100 \mathrm{~cm} / 10^{3}$ years for H-layer-1 (Andrews et al., 1994). A similar rate of up to $110 \mathrm{~cm} / \mathrm{ky}$ was obtained for H-layer 2 in this study.

Estimates of iceberg flux rates on the order of $10^{3} \mathrm{~km}^{3} /$ year (Miller and Kaufman, 1990; Dowdeswell et al., 1995, Cortijo et al., 1997) suggest that "armadas" of icebergs were drifting during H-events in the North Atlantic north of $40^{\circ} \mathrm{N}$. Iceberg cover increased sea surface albedo and, more importantly, through melting generated a fresh-water lid that would shut down the thermohaline meridional overturning circulation (MOC) by preventing the North Atlantic Current (Gulf Stream) from penetrating northwards. A much greater volume of fresh-water than from iceberg-melting was supplied by direct melt-water injection from beneath the ice sheets around the North Atlantic (e.g., Hesse et al. 2004; Piper et al. 2012). Without the dense, highly saline Gulf Stream water, the formation of deep water in the Norwegian-Greenland Sea through winter cooling 
would be interrupted. In the absence of heat transport by the Gulf Stream, minimum northern hemisphere temperatures during the final phase of a Bond cycle would result. After considerable thinning or collapse of the LIS towards the end of a H-event, the HSIS would refreeze to its base ending run-away iceberg calving, the melt-water lid on the North Atlantic would disappear, the previous circulation mode would resume (Paillard and Labeyrie, 1994), and the climate would warm rapidly, marking the beginning of a new Bond cycle.

The correlation of Heinrich events with rapid Late Pleistocene climate change may give hints on future global sea-level rise. At present the West Antarctic Ice Sheet (WAIS) is held back from collapsing into the sea by the Ross Ice shelf that forms a buttress preventing major ice streams of the WAIS from surging (Bindschadler 1993; Joughin et al., 1999). Due to slow ocean warming the floating Ross Ice Shelf may break up. This would probably lead to surging of the ice streams that may then pull most of the metastable WAIS into the sea like the Hudson Strait ice stream did during Heinrich events. The result could be a 5-6 $\mathrm{m}$ global sea-level rise in a few decades (Blankenship and Bell, 1993), the most dramatic short-term consequence of gradual global temperature rise. Antarctica may have lost significant ice volume also from the East Antarctic Ice Sheet during the mid-Pliocene warm period betweeen 3 and 3.3 Ma causing an even more dramatic sea-level rise of up to $25 \mathrm{~m}$; however, the evidence is controversial (Balco, 2015).

\section{Materials and methods}

The core material used in this study comprises mostly $10 \mathrm{~cm}$ diameter piston and narrower trigger weight cores obtained during CSS (later: CCGS: Canadian Coast Guard Ship) Hudson cruises Hu75-009, Hu84-030, Hu86-040, Hu87-025, Hu88-024, Hu90-013, Hu92-045, Hu97-048 
and Marion Dufresne II cruises MD 101 and MD99-22. (For core locations see Fig. 6). Xradiographs were made from 1 -cm thick sediment slabs using a Picker Industrial X-radiography unit set at $55 \mathrm{kV}, 15 \mathrm{~mA}$ and ready-packed II Kodak Industrex AA film. Exposure time varied between 12 and 25 seconds depending on compaction-related bulk-sediment density for subsurface depths between 0 and $15 \mathrm{~m}$, on average requiring an increase of $\sim 1 \mathrm{sec} / \mathrm{m}$ subsurface depth. Turbidites and debris flow deposits with their higher bulk densities compared to hemipelagic sediments require 2-3 seconds additional exposure time.

Grain-size was measured by the pipette method for the clay- and silt-sized fractions based on Stokes' law and sieve analysis for sand to pebble-sized fractions. In hemipelagic and pelagic sediments, detrital grains coarser than $150 \mu \mathrm{m}$ are classified as ice-rafted detritus (IRD). Samples of some fine-grained facies (turbid-surface plume sediments and lofted sediments) were analyzed by laser granulometry by the lab of M. Cremer, Bordeaux University, Talence, France.

Stable oxygen - and carbon isotope analyses were performed on 50 handpicked specimen of the planktonic foraminifera Neogloboquadrina pachyderma (sinistral) from the 150-250 $\mu \mathrm{m}$ fraction on a VG-Prism ${ }^{\mathrm{TM}}$ mass spectrometer at GEOTOP (Université de Québec á Montréal; Rashid, 2002) or the $>125 \mu \mathrm{m}$ fraction at Woods Hole Oceanographic Institution (Khodabakhsh, 1997) with an overall analytical error $<0.05 \%$. Results were converted to the Vienna PDB scale (Coplen, 1996) after the usual corrections (Craig, 1997). Radiocarbon ages were determined from 800-1200 handpicked specimens of Nps from the 150-250 $\mu \mathrm{m}$ fraction (Rashid, 2002) or about 2000 specimens $(=15-20 \mu \mathrm{g})$ from the $>125 \mu \mathrm{m}$ fraction (Khodabakhsh, 1997) at Isotrace Lab at the University of Toronto, NOSAMS-WHOI, and the NSF-AMS Facility at the University of Arizona. The reservoir age for the northwest Labrador Sea samples that has to be subtracted from the measured results is 450 years. The ages were calculated using Libby's ${ }^{14} \mathrm{C}$ half life after isotopic 
normalization for a $\delta^{13} \mathrm{C}$ value of $-25 \%$.

Geochemical analyses comprised bulk carbon content, carbonate content (=inorganic carbon) and total organic carbon (TOC) measured on $0.5 \mathrm{~g}$ of dry sample material using a LECO CS-125 infrared analyser. The carbonate content (=inorganic carbon) was measured in a $\mathrm{CO}_{2}$ Coulometer. The inorganic-carbon samples were first heated at $550^{\circ} \mathrm{C}$ for 2 hours. The type of organic matter was characterized by Rock-Eval pyrolysis at the Geological Survey of Canada, Energy and Environmental subdivision, Calgary. The chemical composition of feldspars and ash fragments was determined using a scanning electron microscope (SEM) combined with an energy-dispersive system (EDS) at the Université de Québec á Montréal set at an accelerating voltage of $25 \mathrm{kV}$ and a beam current of $0.5 \mathrm{~A}$.

Magnetic susceptibility was measured every $3 \mathrm{~cm}$ on whole cores and integrated over about $5 \mathrm{~cm}$ of core length using a Bartington magnetometer. Sediment colour (i.e., the L-parameter and the $\mathrm{a}^{*}$ - and $\mathrm{b}^{*}$-values) was measured every $5 \mathrm{~cm}$ on the split core face with a Minolta CM-2002 digital spectrophotometer, which integrates colour over a circular surface of $\sim 1 \mathrm{~cm}$ diameter. The Lparameter describes the lightness of the measured material with higher L-values characteristic of lighter-coloured sediments; the $\mathrm{a}^{*}-$ and $\mathrm{b}^{*}$-values (not presented here) characterize the chroma (red to green colour content) and the hue (blue to yellow) of the sediment.

\section{Age of Labrador Sea Heinrich Layers}

\subsection{Sequence and age of Labrador Sea Heinrich Layers}

The ${ }^{14} \mathrm{C}$ ages for $\mathrm{H} 0$ to 3 of $10.5,14,21.5$, and $27 \mathrm{ka}$ (corrected for reservoir effect), respectively (Khodabakhsh, 1997; Rashid et al., 2003b), are close to those in the literature for the Labrador Sea and North Atlantic (Andrews et al., 1994a,b; Bond et al., 1993). Calendar years 
equivalent to the radiocarbon ages are 12.9, 16, 24 and $30 \mathrm{ka}$, respectively. Recent work by Lewis et al. (2012) on the Lake Agassiz outburst flood and the $8.2 \mathrm{ka}$ cold event has shown that the conventional reservoir correction of 450 years is insufficient for this event because of the prolonged annual sea ice cover and deflection of the Gulf Stream at that time which shorten the contact of the near-surface oocean water in which planktonic foraminifera live with the $\mathrm{CO}_{2}$ of the atmosphere. These authors added 200 years to the reservoir correction. Haflidason et al. (2000) discussed required reservoir corrections as high as 800 years. Although similar scenarios likely apply to Heinrich events, we do not have data on the annual extent of the sea-ice cover during Heinrich events and therefore cannot apply this correction.

For differences of the age estimates for $\mathrm{H} 4$ to $\mathrm{H} 6$ see Table 1. The additional H-layer 5a between 620 and $790 \mathrm{cmbsf}$ (cm below sea floor) in core Hu90-013-29 occurs above H-layer 6 between 950 and 975 cmbsf and is dated as being slightly younger than the age of ash zone AZ-2 (at 820-830 cmbsf) of 52-53 ka (Ruddiman and Glover, 1972). H6 was assigned an age of 66 -67 ka by earlier studies (Bond et al., 1993; Grousset et al., 1993), which is poorly constrained. Discovery of the additional event H5a by Rashid et al. (2003b) halves the long time span of 14-15 kyr between H5 and H6 and makes the recurrence intervals between the older H-events commensurate to the average recurrence interval of $7.4 \mathrm{kyr}$ (Sarnthein et al., 2001). For the older H-layers HL-5a and HL-6, ice-rafted ash layers provide some age constraints.

\subsection{Labrador Sea ash-layer stratigraphy}

In addition to ash zones AZ-I and -II in the North Atlantic, dated 9.3 and $65 \mathrm{ka}$, respectively (Ruddiman and Glover, 1972), Khodabakhsh (1997) for the first time identified five ash layers (AL-1 to -5) between AZ-I and AZ-II in the northwestern Labrador Sea. Their correlation is shown 
in Figure 7A; the ash-layer stratigraphy of other authors for comparison in Figure 7B. AL-I occurs below H-layer 1, Al-2 on top of H-layer 2, and Al-3 below H-layer 3. Al-5 is bracketed by ${ }^{14} \mathrm{C}$ ages of 40.010 and $44.160 \mathrm{ka}$ (which were at the limits of the AMS method at the time the dates were obtained). Haflidason et al. (2000) reviewed the Middle and Late Quaternary tephrochronology in the Iceland and North Atlantic regions. Abbott et al. (2011) discovered two new ash layers during MIS 5a to 4, spanning the time from $\sim 82$ - $60 \mathrm{ka}$, the crucial time of pronounced cooling during the initiation of the last glaciation. AL-2 has the highest ash-particle concentration (>300/g) of all layers. The glass shards are of basaltic or rhyolitic composition. The brown to black basaltic grains are predominant; the clear and colourless rhyolitic grains dominate AL-5. The chemical composition of the two groups is given in Table 2.

\section{Depositional facies, petrology and geochemistry of Heinrich layers}

\subsection{Depositional facies of Heinrich layers}

X-radiographs of the eight most recent H-layers (HL-0 to 6) in the northwestern and central Labrador Sea allow the differentiation of five sedimentologically distinct types of depositional facies (Fig. 8) all of which include detrital-carbonate rich mud, except in type I where it is subordinate. In proximal to distal order with respect to the Hudson Strait source these are: Type I H-layers consisting of thick, massive ice-rafted layers. Type II H-layers made up of stacked centimetre-thick layers of graded mud spiked with coarse grains of IRD reaching a cumulative thickness of the stacked layer-sequences of up to several meters. In type III, millimeter- to centimeter-thick mud turbidites alternate with thin laminae of IRD. Type IV comprises centimetrethick crudely laminated layers of IRD interbedded with thin mud turbidite beds. Type V is made up of bioturbated muds with coarser IRD and a small (hemi-) pelagic component, represented by small 
numbers of foraminifera. Mineralogically, the five types are similar, although some proximal-todistal variations, especially in organic-matter content and reported isotopic variations, are related to the different distance from the source areas of types I (proximal) to $\mathrm{V}$ (distal) and different provenance.

Type-I H-layers have been observed with H-layers 3, 4 and 5 in the most proximal cores 97$048-7,-14$, and in cores $90-013-25,-26,-28,-29,-33,-34,92-045-6$ and 88-025-11,-13 in intercanyon regions on the slope. They consist of massive ice-rafted layers with some indication of horizontal bedding produced by $\leq 1 \mathrm{~mm}$ thick laminae of hemipelagic mud that may be wavy. In some cores they contain thin interspersed laminae or layers of turbidite mud showing a transition to type III layers. Type I was formerly (Hesse and Khodabakhsh, 1998) included in what is now classified as Type II.

Type-II H-layers consist of successions of layers of yellowish to greyish brown (Munsell color chart $2.5 \mathrm{Y} 5 / 2$ to $10 \mathrm{YR} 5 / 2)$ and brownish-grey (2.5Y 6/2 and 10YR 6/2) graded silt to silty clay with interspersed coarse-sand and granule sized grains (II in Fig. 8; Fig. 9). The bimodal grain-size distribution shows a main mode in the coarse (base of layer) to fine (top of layer) silt-sized fractions and a secondary mode in the granule and coarse sand fractions (Fig. 10A). Some out-sized pebbles display dropstone structure (see below). Bioturbation is moderate to rare. H-layers of type II reach $>1 \mathrm{~m}$ thickness to a maximum of $3.65 \mathrm{~m}$ (i.e., H-layer 1 in core 97-048-9, Fig. 3A, the thickness of $4.20 \mathrm{~m}$ in Rashid et al. (2003b) has been corrected) and generally comprise tens of individual graded mud layers 0.2 to $5 \mathrm{~cm}$ thick, the basal one commonly having a sharp base with some evidence for erosion of underlying hemipelagic sediment (see Supplemental data: Figs. 1-3).

This type and the ice-rafted portions of type-III H-layers have the highest carbonate content (up to $41 \%$, Tab. 3) among all depositional facies in Labrador slope and basin. Most of it is of detrital 
origin. Biogenic carbonate in H-layers constitutes only trace amounts ( $<100$ foraminifera/g). More than $80 \%$ of the detrital carbonate is contained in the fine grain-size fractions $(<63 \mu \mathrm{m}$, i.e., silt and clay-sized material; Khodabakhsh, 1997). The average organic carbon content (1.4\%) is significantly higher than in interbedded hemipelagic sediments, but lower than in mud turbidites from the same core (Fig. 11). Low hydrogen indices (average HI for core 90-26 = 103) and high oxygen indices (average $\mathrm{OI}=470$ for the same core) determined by rock-eval analyses indicate a predominantly terrestrial source of the organic matter (Fig. 12 A, B). Diagenetically, the organic matter is mostly immature to semimature. Compared to hemipelagic sediment with little IRD, typeII H-layers have a higher OI (average of 666 in Fig. 12A, B vs. 317 for hemipelagic sediment), indicating a higher proportion of land-derived organic matter in ice-rafted layers. This may be plant material from interglacial times, picked up by the basal ice during renewed advance of the LIS and then transported by icebergs to the sea. Rashid and Grosjean (2006) on the other hand used organic geochemistry as a tool for source-area determination and identified Middle to Upper Ordovician and Silurian host rocks of the Hudson Bay region as source rocks.

Type-III H-layers are made up of alternations of millimetre to centimetre thick, greyish brown to dark brown $(2.5 \mathrm{Y} 5 / 2$ to $5 \mathrm{Y} 5 / 1)$, carbonate-rich silty mud turbidites with millimetre thick laminae of IRD, occasionally only one-grain layer thick. Outsized pebbles display typical "dropstone structure" (Harrison, 1975), in which the underlying sediment is deformed, apparently by impact of the clast, while overlying laminae drape the clast, thus providing firm evidence for icerafting (Fig. 8: III). The mud turbidites are either parallel laminated silty-clayey sediment $\left(T_{d}\right.$ turbidite structure division) and/or homogeneous pelitic sediment $\left(\mathrm{T}_{\mathrm{e}}\right)$, but rarely display a $\mathrm{T}_{\mathrm{c}}$ division of small-scale ripple cross-lamination at the base. The turbidites are free of IRD. This is the distinct difference compared to the graded mud layers of type-II H-layers. The occasional ice-rafted 
grain that may be mixed into a turbidite, mostly into the bottom or top part, was incorporated either as an artifact during slicing of the samples for X-radiography, or by iceberg release during deposition. Sediment sorting (Fig. 10) for the mud turbidites of type III H-layers is best among all facies encountered in Labrador slope and basin (Wang and Hesse, 1996). Bioturbation is generally absent. The organic carbon content of the mud turbidites of this facies from the Labrador slope is the highest among all sedimentary facies from the Labrador Sea (Fig. 11).

Type-IV H-layers like type III consist of alternations of detrital-carbonate rich mud turbidites and layers of IRD, but the thickness ratio between the turbidites and layers of IRD in type IV is the reverse of that in type III: the IRD layers are thicker than the turbidites, and there are much fewer turbidites per H-layer than in type III (Fig. 8: IV). There is some bioturbation in type IV whereas bioturbation is absent in type III (Fig. 8).

Type-V H-layers consist of olive grey ( $5 \mathrm{Y} 4 / 1$ to $5 / 2)$, grey (2.5Y 5/1 5Y 5/1) and dark gray (5Y 6/2) sandy-gravelly mud without size grading. The sediment is coarser (mean grain size $=5.7 \varphi$ ) and less well sorted $(\sigma=2.5 \varphi)$ than hemipelagic mud without IRD (mean $=7.2 \varphi, \sigma=2.0 \varphi$ ). The grain-size distribution is polymodal with a prominent mode in the clay and silt fractions and subordinate modes in the sand and gravel fractions, much different also from the type-II H-layers displaying a minimum in the fine-sand to coarse-silt fractions (Fig. 10). Compared with pure (hemi) -pelagic sediments, bioturbation is less intense. Foram numbers are typically low as for the other types of H-layers ( $<100$ forams/g), whereas in (hemi-) pelagic sediments containing IRD that occur between H-events, foraminifera numbers may be higher (up to 1000 forams/g)(Groussset et al., 1993; Khodabakhsh, 1997). The petrography of the IRD also differs: in H-layers detrital carbonate is abundant; in ice-rafted sediment between $\mathrm{H}$-events siliciclastic detritus predominates (Khodabakhsh, 1997). 


\subsection{Geochemical signatures of Heinrich layers}

Oxygen-isotope values of the planktonic foraminifera Neogloboquadrina pachyderma (sinistral) in sediments during Heinrich events show the lowering of the $\delta^{18} \mathrm{O}$ as a combined temperature and melt water effect, as mentioned in the introduction (Fig. 13). As detrital carbonate content goes up to $15-30 \%$ from generally $<5 \%$ between $\mathrm{H}$-layers, bulk-carbonate $\delta^{18} \mathrm{O}$ values are depleted by 5\% (Hodell and Curtis, 2008), because Lower Paleozoic detrital carbonate is isotopically lighter. Detrital carbonate content is the safest criterion to use for the identification of the top of Heinrich layers, if highresolution carbonate analyses are available.

Small et al. (2013) used U-Pb ages of detrital rutile and zircon grains as a tool to determine provenance. The bimodal age signatures of rutile in IRD ( 470 Ma and 1,800-2,600 Ma) suggests a Laurentian contribution besides Scotland. It implicates the involvement of the Atlantic meridional overturning circulation in the distribution of IRD and "supports the interpretation of Heinrich layers as timeparallel marker horizons". The composition of detrital feldspars also serves as a provenance indicator (Windley, 1969; Chough et al. 1987). Anorthositic plagioclase of low to intermediate An content (average An of $20.7 \%$, range: $0-42 \%$ ) is derived from Canadian sources (braid plain sands east of NAMOC). Plagioclase in Greenland Slope sands on the other hand shows intermediate to high An contents (average 61.5\%, range 16-100\%) (Khodabakhsh, 1997, fig. 4.15).

\section{Distribution of Heinrich layers in the Labrador Sea and depositional mechanisms of formation}

\subsection{Distribution and isopachs}

The five sedimentologically different types of H-layers occur in mostly disjunct regions of the Labrador Sea and North Atlantic without much overlap (Fig. 14). Type-I H-layers are restricted to 
the most proximal upper Labrador Slope and the crest of intercanyon regions on the slope. Type II layers occur on the Labrador Slope and upper Rise south of the terminus of the HSIS next to and overlapping in part with type I layers (from here on Fig. 14). Types III and IV occur where the flow paths of turbidity currents spilling over from canyons and channels lie under the iceberg drift route. They occur in the region of the middle slope (type III) and on the NAMOC levees (type IV). Type V occurs in the most distal regions of the Labrador Sea (with respect to the Hudson Strait source) and in North Atlantic and on seamounts, which were not reached by turbidity currents or lofting sediment columns. All five types may form during the same event. Type-I layers have only been observed with Heinrich Events 3, 4 and 5.

Isopachs of individual H-layers show two maxima, one in the vicinity of the Hudson Strait outlet and another smaller one in the North Atlantic near $45^{\circ} \mathrm{N}$ latitude (Fig. 4 A,B). In Ruddiman's (1977) ice-rafting belt between 40 and $50^{\circ} \mathrm{N}$ maximum fluxes of IRD are enclosed by the $250 \mathrm{mg} / \mathrm{cm}^{2} / \mathrm{kyr}$ isoflux line and reach values in excess of $600 \mathrm{mg} / \mathrm{cm}^{2} / 10^{3}$ years during the $25-13 \mathrm{ka}$ time slice. Exceptional thicknesses >1 m are reached by H-layer 1 (3.64 m in core 97-048-09, Fig. 5B), H-layer 2 (326 cm in core 97-048-140), H-layer 3 (exceeding $3.36 \mathrm{~m}$ in core 97-048-14, in which the bottom is not exposed due to core suck-in) and H-layer 5a (325 cm in core 90-013-28 in the northwestern Labrador Sea around $60^{\circ} \mathrm{N}$, whereas H-layer thicknesses in the mid-latitude icerafting belt between 40 and $50^{\circ} \mathrm{N}$ rarely exceed $35 \mathrm{~cm}$ (Fig. 4 A,B). Since the most rapid iceberg melting and release of IRD are expected for the mid latitudes where the icebergs meet the North Atlantic Current (Gulf Stream), but not in the cold northern climate, unless melting of the basal debris-rich zone of icebergs was extensive in the proximal regions in the north as suggested for some type-I H-layers (see also Dowdeswell et al. 1995), this thickness anomaly requires an alternative explanation in terms of the depositional mechanisms of ice-proximal H-layers. Apart 
from this anomaly, the isopach pattern shows the expected proximal to distal thickness variations with respect to the major iceberg outlets of the LIS (Hudson Strait and Gulf of St. Lawrence) and the assumed paleoposition of the centre of the Gulf Stream.

\subsection{Depositional mechanisms}

Deposition of the five types of H-layers is explained by a combination of different particle transport mechanisms: type I is dominated by ice rafting simultaneous with minor hemipelagic sedimentation or spill-over turbidity-current activity, type II by ice rafting combined with deposition from lofted sediment columns; type III by deposition from high-frequency turbidity currents spilling over from submarine canyons combined with ice-rafting between the turbidite episodes; type IV by deposition from low-frequency turbidity currents spilling over from the deep NAMOC and ice-rafting in the longer time intervals between the currents; type V by ice-rafting and (hemi-) pelagic settling.

Type-I Heinrich layers: Massive ice-rafted layers with interspersed wavy horizontal laminations

These H-layers form in the most proximal areas or on the crest of intercanyon regions on the slope where ice-rafting dominates and the influence of hemipelagic sedimentation or spill-over activity of turbidity currents is subordinate. Despite the lack of significant auxiliary transport and depositional mechanisms, some of the most proximal type-I H layers reach >1 m thickness, i.e. $\mathrm{H}$ layer 3 in core $97-048-14(3.59 \mathrm{~m})$ and H-layer 4 in the same core $(1.43 \mathrm{~m})$ attesting to rapid meltout from the debris-rich basal layers of icebergs shortly after calving.

Type-II Heinrich layers: Lofted sediments 
The outstanding characteristic of type-II H-layers is the combination of graded bedding with coarser particles floating in the graded layers (II in Fig. 8) producing a bimodal size distribution (Fig. 9).. An explanation for this combination of incompatible grain-size populations requires a depositional mechanism, which is slow enough to incorporate ice-rafted debris, but fast enough to prevent extensive bioturbation. It was originally thought that nepheloid layers, in contrast to turbidity currents, would be capable to provide a mechanism to incorporate IRD in graded mud layers (Wang and Hesse 1996). However, the particle concentration of nepheloid layers is insufficient (McCave, 1986) to produce the thickness of the IRD-spiked graded mud layers. As an alternative, Hesse et al. (2004) suggested sediment lofting as a mechanism to explain the cooccurrence of incompatible grain-size populations in type II H-layers.

Sediment lofting from turbidity currents is a process that occurs in density currents generated from fresh-water discharges into the sea and other gravity currents that can produce reversed buoyancy. In the process, parts (or all) of a turbidity current lift(s) up from the substrate on which it flows due to buoyancy reversal. This is possible in currents containing fluid (fresh water) that is less dense than the ambient fluid (seawater). Settling of suspended sediment from the top or deposition from the bottom of the flows may lower their bulk density below that of ambient seawater causing the currents to lift up from the substrate either in part or as a whole through buoyancy reversal, as is well known from experiments (Sparks et al., 1993). In currents which may not lift off from the bottom as a whole, a surface layer of reduced density develops at the top by loss of suspended particles due to settling into lower levels of the turbulent flow, and this diluted surface layer starts to separate from the body of the current and rises as a low-velocity suspended-sediment column (Fig. 15). Fine-grained sediment lofting on a large scale during times of Heinrich events has been inferred for the northwest Labrador Sea adjacent to the margin 
of the Late Pleistocene LIS (Hesse and Khodabakhsh, 2006).

The freshwater turbid clouds buoyantly rising out of the currents would spread horizontally once they encountered a level of equal density in the stratified water column, either the pycnocline or the sea surface, where they would form (inter-) flows moving in different directions even upstream. From these laterally spreading flows the deposition of graded mud layers would start. Deposition from (inter-) flows of fine-grained suspended sediment lofted from large turbidity currents occurs concomitantly with ice rafting as the distribution of IRD in the graded mud layers shows. The mechanism provides the unique combination of two depositional processes operating in tandem at comparable speed. Such a combination of hydrodynamically different processes is needed to explain the unusual coincidence of size grading and outsized grains in the deposits for which no equally compelling alternative explanation exists. Each (inter) flow would represent a seasonal single waning-flow or waning-concentration episode, in the course of which the initial inrush produces a basal layer of coarse silt followed by more claysized material later in the season before both fluxes ceased in winter. Dispersal of the IRD throughout some of the graded mud layers suggests that the two processes - ice rafting and the delivery of the fines by lofting and lateral spreading of the (inter-) flows - occurred simultaneously. The absence of separate lamina of IRD between most successive lofted-layer deposits attests to the distinct difference between type-II H-layers and turbidite-bearing types III and IV.

Suspended sediment concentrations in meltwater are normally insufficient $(<40 \mathrm{~g} / \mathrm{l})$ to exceed the density of cold seawater (Syvitski et al., 1987). However, in front of the Hudson Strait outlet, huge sand-carrying outburst floods during Heinrich events broke the density barrier of seawater and formed turbidity currents that built a giant abyssal sand plain (Fig. 16) comprising a volume of 
$700 \mathrm{x} 120 \mathrm{x} 0.15 \mathrm{~km}^{3}$ (length $\mathrm{x}$ width $\mathrm{x}$ average thickness), that is, $\sim 12,500 \mathrm{~km}^{3}$ of coarse-grained sand, one of the largest sand accumulations on Earth (Hesse et al., 2001; Hesse and Khodabakhsh, 2006). From these flows the fresh-water suspended-sediment columns rose that deposited the lofted sediment facies of type-II H-layers.

Type-III H-layers: Mud-turbidites alternating with laminae of IRD

The mud turbidites of type-III H-layers (Fig. 8: III) are generally free of IRD, because deposition from turbidity currents is too fast to allow the incorporation of IRD. The occurrence of individual laminae of ice-rafted material between the turbidites shows that the time between the passage of successive turbidity currents was sufficient for the accumulation of visible laminae of IRD. Since low-density turbidity currents in the slope canyons are commonly triggered by the slumping of fine-grained turbid-surface plume deposits on the upper slope (Wang and Hesse 1996; Hesse et al. 1997a), rather than by the direct introduction of this material through discharge events at the ice margin, these flows would not be melt-water generated. The time required for the formation of an individual lamina of IRD between successive turbidites in type-III H-layers likely exceeds one year.

\section{Type-IV H-layers: Layers of ice-rafted debris with intercalated mud-turbidites}

The smaller number of turbidites in type-IV H-layers (Fig. 8:IV) reflects the lower frequency of spill-over events from the up to $200 \mathrm{~m}$ deep NAMOC compared to type-III H-layers, whose mud turbidites are derived by more frequent spillover events from the less deep lower-slope canyons. This difference is corroborated by the somewhat higher intensity of bioturbation in typeIV H-layers. Previously, the ice-rafted layers of type-IV were interpreted as "headspill" turbidites, 
i.e. a special type of turbidites that resulted from the spillover of the head of turbidity currents (Chough and Hesse, 1980; Hesse, 1995). The associated mud turbidites, which cap these coarser layers, were interpreted as body-spillover deposits of the same currents on the NAMOC levees. Large turbidity currents in channels with a relatively high slope gradient have a head which is thicker than the body that can produce its own spill-over deposit followed by a bodyspill turbidite. However, the characteristics used as arguments for the presence of headspill deposits, namely the lack of bioturbation and foraminifera, the absence of grading, and poor sorting, are the characteristics of H-layers as described above. While in type-IV H-layers the gravelly-sandy muds are ice-rafted in origin, as supported by the presence of dropstone structure, the parallel-laminated or graded or homogeneous mud interbeds were deposited by the spillover of the fine-grained top layers of turbidity currents from the deep channel. Individual pebbles as large as $1.5 \mathrm{~cm}$ are present in the gravelly-sandy mud of the H-layers. If they were mass-flow deposits, debris flows could have been the transport agent for such poorly sorted material. However, debris flow deposits (Facies D in

Fig. 17) can be texturally differentiated from hemipelagic sediment containing IRD. Both by chronologic and lithologic correlation, the layers on the NAMOC levees containing coarse IRD and very few foraminifera are identified as H-layers (Fig. 18).

Type-V H-layers: Fine-grained hemipelagic sediment deposited from suspended particles and dropstones and-grains supplied by ice rafting

Deposition of coarse and fine-grained detrital carbonate in type-V H-layers occurred by the rainout of iceberg-released material, as in type-IV, but without intercalated mud-turbidites. The occurrence of type-V H-layers in distal regions with respect to the major ice outlets or on topographic highs such as seamounts, inaccessible for turbidity currents, is in line with this 
interpretation (see also Hiscott and Aksu, 1996). Slow deposition after the H-event allowed for some bioturbation of the thin sediment layers. The paucity of planktonic foraminifera shows that the bulk of the carbonate was supplied by the settling of suspended detrital sediment; true pelagic constituents remain subordinate.

\section{Discussion}

\subsection{Heinrich layer thickness anomalies}

From the inferred depositional mechanisms for H-layer types I to IV, the anomalous thickness distribution with the two maxima referred to above is readily explained: The unexpected high thickness in the north results primarily from auxiliary depositional mechanisms, i.e. sediment lofting, surface plumes, turbidity currents and other mass flows, which significantly contributed to increase the thickness of H-layers in ice-stream-terminus proximal regions. In distal regions, icerafting alone was responsible for H-layer deposition, resulting generally in lower thicknesses, despite more rapid melting in the lower latitudes, where the icebergs encounter the Gulf Stream. Although release of debris from the basal debris-rich zone of icebergs can cause some thickness anomaly during the initial melting, the low water temperatures in the north should minimize this effect, except in the ultraproximal sites of type-I H-layers off the HSIS and unusual thicknesses of H-layer-2 (62 and $54 \mathrm{~cm})$ seawards of the Gulf of St. Lawrence/Laurentian Channel outlet of the

\section{LIS (Fig.4A, B).}

H-layers may also show up on seismic profiles. This is one possible interpretation for the prominent seismic marker horizons that are observed on a seismic profile across a broad ridge between slope canyons NBABBD and NCABA south of the Hudson Strait outlet (Fig. 19). Tripsanas and Piper (2008) correlated seismic reflectors in Orphan Basin with Heinrich layers. 


\subsection{Fine-fraction detrital carbonate anomaly}

The complex depositional processes unravelled for the ice-proximal H-layers also explain the anomalously high proportion of detrital carbonate in the fine-grained fractions $(<63 \mu \mathrm{m})$ in $\mathrm{H}$ layer types II to IV. Whereas in modern icebergs more than about $60 \%$ of the debris are coarser than $63 \mu \mathrm{m}$ (Table 4), in type II to IV H-layers $<20 \%$ of the detrital carbonate occur in the coarser grainsize fractions, and $>80 \%$ in the fine fractions (Table 3). It is possible that Pleistocene icebergs from the LIS had a higher proportion of fines compared to that seen in modern icebergs due to efficient grinding of the Paleozoic carbonates forming the substrate of large parts of the north-eastern sector of the ice sheet (Hiscott and Aksu, 1996). However, the discrepancy is too large for this explanation to be satisfactory. Discharge of high concentrations of suspended fine-grained carbonate as "glacial flour" or "glacial milk" in lofted sediment columns or turbid-surface plumes, however, can explain the compositional anomaly of the proximal H-layers. In the case of turbid surface-plumes, rain-out of the sediment on the slope (Hesse et al. 1997b) and remobilization by slumps and turbidity currents are involved as additional intermediate transportation steps before the sediment can be incorporated into the turbidites of H-layers (of types III and IV).

\subsection{Incomplete stratigraphic sequence of Heinrich layers}

In the Labrador Sea cores studied (Supplement Fig. 8), the sequence of H-layers may be incomplete for different reasons. For example, H-layers older than $\mathrm{H} 2$ were not encountered in cores from the NAMOC levees (HU 75-009 and 87-025 cores) because of the great thickness of the sequence of spillover turbidites below this layer, which was not penetrated to its base. Because of 
insufficient penetration, H-layers older than H3 were also not encountered in cores 75-009-55, -61, -62 on the slope off the Hudson Strait, and H-layers older than H4 not in cores to 88-024-10 on the slope south of the Strait. Stratigraphic penetration was greatest (due to great core length, relatively low sedimentation rates, extensive core-top loss, or erosion by debris-flows or a combination of these factors) in cores 97-048-07, 88-024-11, 90-013-25, -26, -28, -29 and 92-045-06, which are the only cores that encountered H5 shown here for the first time in X-radiographs (Fig. 20). The event H5a also shown here for the first time in X-radiographs is present in three Hudson cores (90-13-28, -29, 92-45-06, possibly also 88-24-11) and three Marion Dufresne cores (MD 95-22, -24, -25, Fig. 21) (see Rashid et al., 2003a, figs. 4,5), whereas H6 was encountered only in core 90-013-29.

H1 is absent in a number of cores (in centre of Supplement Fig. 8 from core 88-24-11 to 9045-34) apparently due to core-top loss during coring operations. H3 is missing from a number of cores (e..g., 92-45-05, 90-13-26, 88-24-10 and 88-24-11), probably because it was removed by debris flows at these core sites. Studying seismic reflection profiles Rashid and Piper (2007) concluded that grounded Laurentide ice of the HSIS crossed the continental shelf during H3 and delivered glacigenic debris flows to the continental slope. The distribution pattern and provenance of $\mathrm{H} 3$ in the North Atlantic is still not well established and its provenance is being debated. In the present study it was identified in 13 cores (see also Rashid et al., 2003c). Grousset et al. (1993) determined a different mineralogical composition (i.e. no detrital carbonate) for the North Atlantic H3 and postulated a Greenlandian source for this layer. However, in the northwestern Labrador Sea, the high detrital carbonate content of H3 indicates a source similar to that for H1, 2 and 4, i.e. the Hudson Strait, although Andrews et al. (1994a) and Kirby and Andrews (1999) suggested that its source changed from down the Hudson Strait to possibly Ungava Bay. A re-examination by Bond and Lotti (1995) of the cores from the North Atlantic studied by Grousset et al. (1993) also suggests 
the presence of a Hudson Strait component in the ice-rafted material of $\mathrm{H} 3$.

A number of piston cores (Fig. 22) from positions in the eastern half of the Labrador Basin east of the NAMOC contains little IRD and does not contain identifiable H-layers for different reasons. It could mean that a region in centre of the basin east of NAMOC was not under the iceberg drift route during $\mathrm{H}$-events comparable to the present situation. The isopachs for H-layers would be discontinuous and could not be extrapolated across the basin centre, in contrast to the reconstruction of Dowdeswell et al. (1995). However, these cores come from the extensive braided submarine sand plain (Hesse et al., 2001) already referred to. The apparent absence of H-layers in this region except in core 84-7 (Fig. 22) might simply be due to the denudation by and incorporation into the turbidity currents that deposited the massive sand layers of the abyssal sand plain.

\section{Origin of Heinrich events}

Four models have been suggested for the origin of Heinrich events. The binge-purge model of MacAyeal (1993) is based on assumptions concerning geothermal heat flow and ice sheet thickness. When the LIS reached its greatest thickness, increased thermal insolation resulted in melting of the basal ice producing wet-based glaciers. Wetted basal till would be deformed and serve as a lubricant at the base of major icestreams leading to glacial surges through the Hudson Strait and other outlets of the LIS that would initiate ice-rafting events. After sufficient thinning of the LIS the ice sheet would refreeze to its base, ice-berg shedding would stop and a new Bond cycle would commence.

An alternative scenario is based on glaciological evidence (e.g., tunnel valleys; Boyd et al., 1988; subglacial meltwater flooding through lakes Ontario and Erie, Lewis and Todd, 2015). Hesse et al. (1995) and Johnson and Lauritzen (1995) suggested that subglacial outburst floods 
(jökulhlaups) from lakes dammed by ice in Hudson Strait may have caused extensive iceberg discharges.that may have initiated Heinrich events. Evidence supporting the subglacial outburst model includes canyons exposed in the Hudson Strait on land (the York canyons on the Meta Incognita Peninsula), which presumably acted as spillways for the outburst events (Johnson and Lauritzen, 1995), but also the occurrence of a huge submarine braided sand plain in the central Labrador Basin east of the NAMOC (Hesse et al. 2001). This braidplain seems to have received its sediment from sheet-flow like turbidity currents originating on the slope in front of the Hudson Strait that initially bypassed the NAMOC. The presumed size of these currents requires sediment and water reservoirs which could best be matched by subglacial lakes in the Hudson Strait that might have been emptied catastrophically when the ice barriers or end moraines damming such lakes at the mouth of the strait were lifted or cut during H-events. The sand plain did not receive its sediment from turbidity currents overspilling the eastern NAMOC levee. The sharp base of most Hlayers, particularly of the proximal H-layers of type-II, suggests that the first flow associated with an event may have been particularly vigorous because it was related to outburst flooding and may have caused erosion before starting to deposit sediment from a lofted sediment column (Supplement Figs. 1-3).

The binge-purge model would explain the periodic recurrence of Heinrich layers, if they were not fed from the 3 or 4 northern-hemisphere ice sheets and caps synchronously (Grousset et al., 2000, 2001). If ice sheet collapse occurred synchronously in North America, Greenland, on Iceland and Northern Europe, then external control by orbitally forced climate change is more likely (Bond and Lotti, 1995), in which case outburst-flooding could have been the triggering event through sea-level rise (Gwiazda et al. 1996). Such events need not be restricted to H-events and might have been associated with the shorter millenial-scale periodicity of Dansgaard-Oeschger 
climatic oscillations (Johnson and Lauritzen, 1995).

A fourth hypothesis is based on the ice-shelf break-up model of Hulbe (1997) and Hulbe et al. (2004) triggered by climate change or sea-level rise initiated by the collapse of other northernhemisphere ice sheets, i.e. the Fennoscandian Ice Sheet which has been inspired by the catastrophic break-up of ice shelves in the Weddell Sea in West Antarctica during the last decades. An ice shelf in front of the HSIS, if it existed at the time preceding a H-event, would have served as a buttress, its break-up and disappearance due to sea-level rise would have allowed the HSIS, which is the main drainage outlet of the northeastern sector of the LIS, to surge and trigger a H-event. The basal units of H-layers $\mathrm{H} 0$ and $\mathrm{H} 1$ in Figure 3A might represent material resulting from ice-shelf breakup (pers. commun. D.Piper). A more modern assessment of the likelihood of this mechanism is given by Marcott et al. (2011).

Evaluation of the proposed scenarios for the origin of H-events in the light of the new sedimentological findings concerning the mechanism of emplacement of H-layer type II suggests that the outburst-flooding hypothesis for the origin of H-events is unlikely. Identification of the lofting mechanism as depositional process for type II H-layers implies that the stack of graded layers with floating ice-rafted grains was deposited by a sequence of annual events because the absence of IRD laminae or layers between the lofted layers speaks against longer time intervals between the deposition of successive lofted layers. It would then be unlikely that these events were outburst floods sourced from subglacial lakes because of volume considerations.

\section{Conclusions}

Heinrich layers in proximal regions of the iceberg sources of the LIS have a complex origin 
involving auxiliary processes of particle transport that contributed sediment to these layers besides ice rafting and explain their anomalous thickness distribution. The results of this study show that the high concentrations of fine-grained detrital carbonate in H-layers can be supplied by bottomfollowing turbidity flows and lofted sediment columns arising from fresh-water generated turbidity currents. They do not require an ocean with high turbidity from surface to bottom. The level of surface turbidity during $\mathrm{H}$-events though was probably considerably higher than at other times, even in areas far away from major ice outlets because of a presumably higher concentration of finegrained detritus (finely ground up detrital carbonate) in Pleistocene icebergs compared to modern icebergs. Similarly, the great thickness of H-layers in ice-proximal areas does not require a much larger thickness and extent of the LIS than postulated by current models (Fisher et al. 1985; Clark et al. 1996, Stokes et al. 2015). Processes of sediment transport and deposition typical for the vicinity of major ice outlets (and not anomalies of the ice sheet itself) explain the observed anomalies in texture and thickness of the proximal H-layers.

The implications of the relationship of Heinrich events with Late Pleistocene climate change as an analogy for future global climate change is alarming because of the potential 5-6 $\mathrm{m}$ sea level rise that might result from the possible collapse of the West Antarctic Ice Sheet (WAIS) when the breakup of the Ross Ice Shelf removes the buttress for the ice streams of the WAIS. According to Joughin et al. (2014) the break-up of the Ross Ice Shelf is already underway. The outcome of such sealevel rise is the migration of populations of tens to hundreds of millions that would be forced from lowlying areas mostly in southeast Asia, but also in the Netherlands or New York. Thus slow gradual global temperature rise, man-made or triggered by natural causes, can have dramatically devastating consequences. 


\section{Acknowledgements}

This work was supported by grants from NSERC, the Department of Fisheries and Oceans (Ottawa), and the Department of Energy, Mines and Resources (Ottawa) and an Iranian Government Scholarship to S.K.. This support is gratefully acknowledged. Piston cores were obtained on cruises of the CSS Hudson (later: CCGS: Canadian Coast Guard Ship Hudson) between 1974 and 1997 and the Marion Dufresne II in 1995 and 1999. We thank captains, officers and crews for their excellent co-operation and Mark Fay, Martin Honold, Ingo Klaucke, Michelle Lund, Deirdre O'Leary, Gavin Miller, Ann Miller, Allan Rakofsky, Kelly Sears and Dong Wang for assistance at sea. Journal reviewer David Piper provided a very constructive critical review of the manuscript suggesting numerous additional references. Together with an anonymous review the reviewers' comments led to substantial improvements of the manuscript.

\section{References}

Abbott, P.M., Davies, S.M., Austin, W.E.M., Pearce, N.J.G., Hilbert, F.D., 2011. Identification of cryptotephra in a North East Atlantic marine record spanning marine isotope stages 4 and 5a ( 60,000 - 82,000 a b2k). Quaternary International 246, 177-189.

Aksu, A.E., Mudie, P.J., 1985. Late Quaternary stratigraphy and paleoecology of northwest Labrador Sea. Marine Micropaleontology 8, 537-557.

Anderson, J., Domack, E.W., Kurtz, D.D., 1980. Observations of sediment-laden icebergs in Antarctic waters: implications to glacial erosion and transport. Journal of Glaciology 25, 387- 
396.

Andrews, J.T., Barber, D.C., Jennings, A.E. Eberl, D.D., Maclean, B., Kirby, M.E. and Stoner, J. S., 2012, Varying sediment sources (Hudson Strait, Cumberland Sound, Baffin Bay) to the NW Labrador Sea slope between and during Heinrich events 0 to 4. Journal of Quaternary Science 27(5), 475-484.

Andrews, J.T., Erlenkeuser, H., Tedesco, C, Aksu,A., Jull, A.J.T., 1994. Late Quaternary (Stage 2 and 3) meltwater and Heinrich events, Northwest Labrador Sea. Quaternary Research 41, 2436.

Andrews, J.T., Kirby, M.E., Jennings, A.E., Barber, D.C., 1998. Late Quaternary stratigraphy, chronology, and depositional processes on the slope of S.E. Baffin Island, N.W.T.: DC- and Heinrich events and implications for obnshore glacial history. Géography Physique et Quaternaire 52, 91-105.

Andrews, J.T., Tedesco, K., 1992. Detrital carbonate-rich sediments, northwestern Labrador Sea: Implications for ice-sheet dynamics and iceberg rafting (Heinrich) events in the North Atlantic. Geology 20, 1087-1090.

Austin, W.E.N., Wilson, L.J., Hunt, J.B., 2004. The age and chronostratigraphical significance of North Atlantic Ash Zone II. Journal of Quaternary Science 19,137-146.

Balko, G., 2015. The absence of evidence of absence of the East Antarctic Ice Sheet. Geology 43 (10), 943-944.

Barber, D.C. 2001. Laurentide ice sheet dynamics from 35 to $7 \mathrm{ka}$ : Sr-Nd-Pb isotopic provenance of northwest Atlantic margin sediments. Unpublished Ph.D. Thesis, University of Colorado, Boulder, CO.

Bindschadler, R.A., 1993. First annual West Antarctic Ice Sheet (WAIS) science workshop: 
NASA Conference Publication 3222, 58 p.

Blankenship, D., Bell, R., 1993. Delving into the West Antarctic Ice Sheet. Geotimes 38, 12-15. Bond, G. C., Heinrich, H., Broecker, W.S., Labeyrie, L., mcmanus, J., Andrews, J.T, Huon, S., Jantschik, R., Clasen, S., Simet, C., Tedesco, K., Klas, M., Bonani, G., Ivy, S., 1992. Evidence for massive discharges of icebergs into the North Atlantic Ocean during the last glacial period. Nature 360, 245-261.

Bond, G., Broecker, W., Johnsen, S., McManus, J., Labeyrie, L., Jouzel, J., Bonani, G., 1993. Correlations between climate records from North Atlantic sediments and Greenland Ice. Nature $365,143-147$.

Bond, G.C., Lotti, R., 1995. Iceberg discharges into the North Atlantic on millenial time scales during the last glaciation. Science 267, 1005-1010.

Bond, G.C., Showers, W., Elliot, M., Evans, M., Lotti, R., Johnson, S., 1999. The 1.5 kyr cycle of the last glaciation and Holocene: Relation to Dansgaard-Oeschger cycles, Heinrich events and the Little Ice Age. In: Clark, P., Webb, R. And Keigwin, L.D., (eds.), Mechanisms of global climate change at millennial time scales. Geophysical Monography Series 112, 35-58.

Boyd, R., Scott, D.B., Douma, M., 1988. Glacial tunnel valleys and Quaternary history of the outer Scotian shelf. Nature 333, 61-64.

Broecker, W. S., 1994. Massive iceberg discharges as trigger for global climate change. Nature $372,421-424$.

Broecker, W.S., Bond, G., Klas, M., Clark, E., McManus, J., 1992. Origin of the northern Atlantic's Heinrich Events. Climate Dynamics 6, 265-273.

Chough, S.K., Hesse, R., Müller, J., 1987. The Northwest Atlantic Mid-Ocean Channel of the Labrador Sea. IV. Petrology and provenance of the sediments. Canadian Journal of Earth 
Sciences 24, 731-740.

Clark, P.U., Licciardi, J.M., Macayeal, D.R., Jenson, J.W., 1996. Numerical reconstruction of a sift-bedded Laurentide Ice Sheet during the last glacial maximum. Geology 24, 679-682 Cortijo, E., Labeyrie, L., Vidal. L., Vautravers, M., . Chapman, M., Duplessy, J.C., Elliot, M., Arnold, M., Turon, J.L., Auffret, G., 1997. Changes in sea surface hydrology associated with Heinrich event 4 in the North Atlantic Ocean between 40 and 60on. Earth and Planetary Science Letters 146, 29-45.

Dansgaard, W., Johnsen, S. J., Clausen, H.B., Dahl-Jehnsen, D., Gundestrup, N. S., Hammer, C. U., Hvidberg, C. S., Steffensen, J.P., Sveinbjornsdottir, A. E., Jouzel, J., Bond, G. C., 1993. Evidence for general instability of past climate from a 250-kyr ice-core record. Nature 364, 218220.

deGelleke, L., Hill, P.S., Kienast, M. and Piper, D.J.W., 2013. Sediment dynamics during Heinrich event H1 inferred from grain size. Marine Geology, 336, 160-169.

Dowdeswell, J. A., Dowdeswell, E. K., 1989. Debris in icebergs and rates of glacimarine sedimentation: observations from Spitzbergen and simple model. Journal of Geology 97, 221231.

Dowdeswell, J.A., Maslin, M.A., Andrews, J.T., McCave, I.N., 1995. Iceberg production, debris rafting, and extent and thickness of Heinrich layers $(\mathrm{H}-1, \mathrm{H}-2)$ in North atlantic sediments. Geology 23, 301-304.

Ellwood, B.B. and Gose, W.A. 2006. Heinrich H1 and 8200 yr B.P. climate events recorded in Hall's Cave, Texas. Geology 34(9): 753-756. doi: 10.1130/G22549.1

Fillon, R.H. and Duplessy, J.D., 1980. Labrador Sea bio-, tephro-, oxygen isotope stratigraphy and Late Quaternary paleoceanographic trends. Canadian Journal of Earth Sciences 17, 831-854. 
Fisher, D.A., Reeh, N., Langely, K., 1985. Objectivre reconstruction of the Late Wisconsin Laurentide Ice Sheet and the significance of deformable beds. Geographie Physique et Quaternaire 39, 229-238.

Grootes, P.M. and Stuiver, M., 1997. Oxygen 18/16 variability in Greenland snow and ice with $10^{-3}$ to $10^{-5}$ tie resolution. Journal of Geophysical Research 102(C12): 26455-26471.

Grousset, F.E., Cortijo, E., Huon, S., Hervé, L., Richter, T., Burdloff, D., Duprat, J. and Weber, O., 2001. Zooming in on Heinrich layers. Paleoceanography, 16(3): 240-259.

Grousset, F.E., Labeyrie, L., Sinko, J.A., Cremer, M., Bond, G., Dupart, J., Cortijo, E., Huon, S., 1993. Patterns of ice-rafted detritus in the glacial North Atlantic $\left(40-55^{\circ} \mathrm{N}\right)$. Paleoceanography 8 , $175-192$.

Grousset, F.E., Pujol, C., Labeyrie, L., Auffret, G., and Boelaert, A. 2000. Were the North Atlantic Heinrich events triggered by the behavior of the European ice sheets? Geology 28, 123126.

Gwiazda, R.H., Hemming, S.R. and Broecker, W.S. 1996. Tracking the sources of icebergs with lead isotopes: The provenance of ice-rafted debris in Heinrich layer 2. Paleoceanography, 11(1): 371-378.

Haflidason, H., Eiricsson, J. and van Krefeld, S., 2000. Tephrochronology of Iceland and the North Atlantic region during the Middle and Late Quaternary: a review. Journal of Quaternary Science 15 (1), 3-22.

Harrison, S.S., 1975. Turbidite origin of glacial-lacustrine sediments: Journal of Sedimentary Petrology 45, 738-753.

Heinrich, H., 1988. Origin and consequences of cyclic ice rafting in the Northeast Atlantic Ocean during the past 130,000 years. Quaternary research 29, 143-152.

Hemming, S., 2004. Heinrich events: Massive Late Pleistocene detritus layers of the North 
Atlantic and their global climate imprint. Reviews of Geophysics 42, RG1005, doi:10.1029/2003 RG000128.

Hesse, R., 1995. Long-distance correlation of spill-over turbidites on the western levee of the Northwest Atlantic Mid-Ocean Channel (NAMOC), Labrador Sea, in: Pickering, K.T. et al., (eds.), Atlas of deep-water environments: Architectural style in turbidite systems. Chapman \& Hall, Oxford, pp. 276-281.

Hesse, R., Khodabakhsh, S., 1998. Depositional facies of late Pleistocene Heinrich events in the Labrador Sea. Geology, 26, 103-106.

Hesse, R., Khodabakhsh, S., 2006. Significance of fine-grained sediment lofting from melt-water generated turbidity currents for the timing of glaciomarine sediment transport into the deep sea. Sedimentary Geology 186, 1-11.

Hesse, R., Khodabakhsh, S., Klaucke, I., Ryan, W.B.F., 1997b. Asymmetrical surface-plume deposition near ice-outlets of the Pleistocene Laurentide Ice Sheet in the Labrador Sea. Geomarine Letters 17, 179-187.

Hesse, R., Klaucke, I., Khodabakhsh, S., Ryan, W.B.F., Piper, D.J.W., 1995. Icecap drainage into the deep sea. Geological Association of Canada/Mineralogical Association of Canada, Annual Meeting 1995, Final Program and Abstracts 20, A-44.

Hesse, R., Klaucke, I., Khodabakhsh, S., ,Piper, D.J.W., Ryan, W.B.F. and the NAMOC Study Group, 2001. Submarine braid plains: Potential deep-water reservoirs: American Association of Petroleum Geologists Bulletin 85, 1499-1521.

Hesse, R., Klaucke, I., Ryan, W.B.F., Edwards, M.E., Piper, D.J.W., 1996. Imaging Laurentide Ice Sheet drainage into the deep sea: Impact on sedimentation and bottom water. GSA Today 6, 3-9. 
Hesse, R., Klaucke, I., Ryan, W.B.F., Piper, D.J.W., 1997a. Ice-sheet sourced juxtaposed turbidite systems in the Labrador Sea. Geoscience Canada 24, 3-12.

Hesse, R., Rashid, H., Khodabakhsh, S., 2004. Fine-grained sediment lofting from meltwatergenerated turbidity currents during Heinrich events. Geology 32, 449-452.

Hillaire-Marcel, C., de Vernal, A., Bilodeau, G., Wu, G., 1994. Isotope stratigraphy, sedimentation rates, deep circulation, and carbonate events in the Labrador Sea during the last 200 ka. Canadian Journal of Earth Sciences 31, 63-89.

Hiscott, R.H., Aksu, A.E., 1996. Quaternary sedimentary processes and budgets inm Orphan Basin, southwestern Labrador Sea. Quaternary Research 45, 160-175.

Hiscott, R.H., Aksu, A.E., Mudie, P.J. and Parsons, D.F., 2001. A 340,000 year record of ice rafting, palaeoclimatic fluctuations, and shelf-crossing glacial advances in the southwestern Labrador Sea. Global and Planetary Change 28(1): 227-240.

Hodell, D.A., Channell, J.E.T., Curtis, J.H., Romero, E. and Röhl, U. 2008. Onset of "Hudson Strait" Heinrich events in the eastern North Atlantic at the end of the middle Pleistocene transition ( 640 ka)? Paleoceanography 23, PA 4218, doi: 10.1029/2008PA001591. Hodell, D.A. and Curtis, J.H., 2008. Oxygen and carbon isotopes of detrital carbonate in North Atlantic Heinrich events. Marine Geology 256 (1-4), 30-35.

Hoskin, C.M., Valencia, S.M., 1976. Sediment transported by ice-rafting in southern Alaska, in Hood, D.W. and Burrell, D.C., eds., Assessment of the Arctic marine environment: selected topics. Institute of Marine Sciences, University of Alaska, 173-185.

Hulbe, C.L., 1997. An ice shelf mechanism for Heinrich layer production: Paleoceanography 12, 711-717.

Hulbe, C.L., Macaeal, D.R., Denton, G.H., Kleman, J. \& Lowell, T.V., 2004. Catastrophic ice 
shelf breakup as the source of Heinrich event icebergs. Paleoceanography 19, PA1004, doi:10.1029/2003PA000890

Jennings, A.E., Tedesco, K.A., Andrews, J.T., Kirby, M.E., 1998. Shelf erosion and glacial ice proximity in the Labrador Sea during and after Heinrich events (H-3 or 4 to H-0) as shown by foraminifera, in: Andrews, J.T., Auston, W.E.N., Bergsten, H., Jennings, A.E., (eds.), Later Quaternary paleoceanography of the North Atlantic margins. Geological Society, London, Special Publication.

Johnson, R.G., Lauritzen, S.-E., 1995. Hudson Bay-Hudson Strait jökulhlaups and Heinrich events: a hypothesis. Paleogeography, Paleoclimatology, Paleocology 117, 123-137.

Josenhans, H.W., Zevenhuizen, J.,Klassen, R.A., 1986. The Quaternary geology of the Labrador Shelf. Canadian Journal of Earth Sciences 23, 1190-1213.

Joughin, I., Gray, L., Bindschadler, R. Proce, S., Morse, D., Hulbe, C., Mattar, K. and Werner, C. 1999. Tributaries of West Antarctic ice streams revealed by RADARSAT interferometry. Science, 286(5438): 283-286.

Joughin, I., Smith, B.E. and Medley, B. 2014. Marine Ice sheet collapse potentially underway for the Thwaites Glacier Basin, West Antarctica. Science 344, 735-738. doi: 10.1126/science. 1249055

Khodabakhsh, S., 1997. Pleistocene Laurentide Ice Sheet drainage into the Labrador Sea: Sedimentary facies, depositional mechanisms, stratigraphy and significance of Heinrich events: Unpublished Ph.D. Thesis, McGill University, Montreal, QC, 263 p.

Kirby, M., E. and Andrews, J.T., 1999. Mid-Wisconsin Laurentide ice sheet growth and decay; implications for Heinrich events 3 and 4. Paleoceanography 14, 211-223.

Lacasse, C., Sigurdsson, H., Carey, S., Paterne, M. and Guichard, F., 1996. North Atlantic deepsea sedimentation of Late Quaternary tephra from the Iceland hotspot. Marine Geology 129, 207- 
235.

Lackschewitz, K.S. and Wallrabe-Adams, H.J., 1997. Composition and origin of volcanic ash zones in Late Quaternary sediments from the Reykjanes Ridge: Evidence for ash fallout and icerafting. Marine Geology 136, 209-224.

Lewis, C.F.M., Miller, A.A.L., Levac, E., Piper, D.J.W. and Sonnichsen, G.V., 2012. Lake Agassiz outburst age and routing by Labrador Current and the 8.2 cal ka cold event. Quaternary International 260, 83-97.

Lewis, M.C.F. and Todd, B.J., 2015. Evidence for glacial meltwater floods through the Lake Ontario and eastern Lake Erie Basins. Joint Assembly, American Geophysical Union, Geological Association of Canada, Mineralogical Association of Canada, Canadian Geophysical Union, Scientific Program OS32A-05, Montreal, Canada.

MacAyeal, D.R., 1993a. Binge/purge oscillations of the Laurentide Ice Sheet as a cause of the North Atlantic Heinrich events. Paleoceanography 8, 775-784.

Marcott, S.A., Clark, P.U., Padman, I., Klinkhammer, G.P., Springer, S.R., Liu, Z., OttoBliesner, B.L., Carlson, A.E., Ungerer, A., Padman, J., He, F., Cheng, J., Schmittner, A., 2011. Ice-shelf collapse from subsurface warming as a trigger for Heinrich events. Proceedings of the National Academy of Sciences 108, 13415-13419.

McCave, I.N., 1986. Local and global aspects of the bottom nepheloid layer in the modern ocean. Netherlands Journal of Sea Research 20, 167-181.

Miller, G.H., Kaufman, S., 1990. Rapid fluctuations of the Laurentide Ice Sheet at the mouth of Hudson Strait: new evidence for ocean/ice sheet interactions as a control on the Younger Dryas. Paleoceanography 5, 907-919.

Naafs, B.D.A., Hefer, J., Peretti, P., Stein, R., Haug, G.H., 2011. Warm North Atlantic waters 
allow for Heinrich events but prevent major deglaciations. IODP/ICDP Colloquium, German Research Foundation, Münster, Germany, 126 p.

Naafs, B.D.A., Hefter, J., Stein, R. 2013. Millennial-scale ice rafting events and Hudson Strait Heinrich(-like) events during the late Pliocene and Pleistocene: a review. Quaternary Science Reviews 80, 1-28.

Oerlemans, J., 1991. The role of ice sheets in the Pleistocene climate. Norsk Geologisk Tidsskrift $71,155-161$.

Paillard, D., Laberie, L., 1994. Role of the thermohaline circulation in the abrupt warming after Heinrich Events. Nature 372, 162-164.

Piper, D. J.W., Deptuck, M.E., Mosher, D. C., Hughes Clarke, J. E., Migeon, S. 2012. Erosional and depositional features of glacial meltwater discharges on the eastern Canadian continental margin, in: Prather, B.E., Deptuck, M.E., Mohrig, D., Van Hoorn, B., Wynn, R., (eds.), Applications of the Principles of Seismic Geomorphology to Continental Slope and Base-ofslope Systems: Case Studies from Seafloor and Near-Seafloor Analogues. Society for Sedimentary Geology (SEPM), Special Publication 99, 61-80.

Rashid, H., 2002. The deep-sea record of rapid Late Pleistocene paleoclimate change and icesheet dynamics in Labrador Sea sediments. Unpublished .Ph.D. Thesis, McGill University, Montreal, QC, 246 p.

Rashid, H., Grosjean, E., 2006. Detecting the source of Heinrich layers: An organic geochemical study. Paleoceanography 21 (3), PA3014, doi: 1029/2005PA001240

Rashid, H., Hesse, R., Piper, D.J.W., 2003a. Evidence for an additional Heinrich event between H5 and H6 in the Labrador Sea. Paleoceanography 18, doi: 10.1029/2003PA000913 Rashid, H., Hesse, R., Piper, D.J.W., 2003b. Origin of unusually thick Heinrich layers in ice- 
proximal regions of the Labrador Sea. Earth and Planetary Science Letters 208, 319-336.

Rashid, H., Hesse, R., Piper, D.J.W., 2003c. Rashid, H., Hesse, R. and Piper, D.J.W. 2003c. Distribution, thickness and origin of Heinrich layer 3 in the Labrador Sea. Earth Planetary Science Letters, 205(3), 281-293.

Rashid, H. and Piper, D.J.W., 2007, The extent of ice on the continental shelf off Hudson Strait during Heinrich events 1-3, Canadian Journal of Earth Sciences 44 (20), 1537-1549.

Rasmussen, T.L., Oppo, D.W., Thomsen, E. and Lehman, S.J. 2003. Deep sea records from the southeast Labrador Sea: Ocean circulation changes and ice-rafting events during the last 160,000 years. Paleoceanography, 18(1): 1018, doi: 10.1029/2001PA000736

Ruddiman, W.F., 1977. Late Quaternary deposition of ice-rafted sand in the subpolar North Atlantic (lat 40o to 65on). Geological Society of America Bulletin 88, 1813-1827.

Ruddiman, W.F., Glover, L.K., 1972. Vertical mixing of ice-rafted volcanic ash in North Atlantic sediments. Geological Society of America Bulletin 83, 2817-836.

Sarnthein, M. And 18 co-authors, 2001. Fundamental modes and abrupt changes in North Atlantic circulation and climate over the last $60 \mathrm{ky}$ - concepts, reconstruction and numerical modelling. in: Schäfer, P., Ritzau, W., Schlüter, M., Thiede, J. (eds.), The northern North Atlantic: A changing environment, Springer Verlag, New York, pp. 365-411.

Small, D., Parrish, R.R., Austin, W.E.N., Cawood, P.A., Rinterknecht, V, 2013. Provenance of North Atlantic ice-rafted debris during the last deglaciation - A new application of U-Pb rutile and zircon geochronology. Geology 41, 155-158

Sparks, R.S.J., Bonnecaze, R.T., Huppert, H.E., Lister, J.R., Hallworth, M.A., Mader, H., Phillips, J., 1993. Sediment-laden gravity currents with reversing buoyancy. Earth and Planetary 
Science Letters 114, 243-257

.Stanford, J.D., Rohling, E.J., Bacon, S., Roberts. A.P., Grousset, F.E., Bolshaw, M. 2011. A new concept for the paleoceanographic evolution of Heinrich event 1 in the North Atlantic.

Quaternary Science Reviews 30, 1047-1066.

Stokes, Ch.R., Tarasov, L., Blomdin, R., Cronin, T.M., Fisher, T.G., Gyllencreutz, R., Hättestrand, C. Heyman, J.Hindmarsh, R.C.A., Hughes, A.L.C., Jakobsson, M., Kirchner, N., Livingstone, S.J., Margold, M., Murton, J.B., Noormets, R.,Peltier, W.R., Peteet, D.M., Piper, D.J.W., Preusser, F.Renssen, H., Roberts, D.H., Roche, D.M., Saint-Ange, F., Stroeven, A.P., Teller, J.T. 2015, On the reconstruction of palaeo-ice sheets: Recent advances and future challenges. Quaternary Science Reviews 125, 15-49.

Stoner, J.S., Channell, J.E.T., Hillaire-Marcel, C., Kissel, C. 2000. Geomagnetic paleointensity and environmental record from Labrador Sea core MD95-2024: Global marine sediment ice core chronostratigraphy for the last 110 kyr. Earth and Planetary Science Letters, 183(1): 141-177.

Stoner, J.S., Channell, J.E.T., Hillaire-Marcel, C., Mareschal, J.C., 1994. High-resolution rock magnetic study of a late Pleistocene core from the Labrador Sea. Canadian Journal of Earth Sciences 31, 104-114.

Stuiver, M., Grootes, P.M., 2000. GISP2 oxygen isotope ratios. Quaternary Research, 53(3): 277284.

Syvitski, J.P.M., Burrell, D.C., Skej, J.M., 1987. Fjords: processes and products. Springer-Verlag New York Inc.

Thomson, J., Higgs, N.C., Clayton, T., 1995. A geochemical criterion for the recognition of Heinrich events and estimation of their depositional fluxes by the (230Thexcess) 0 profiling method. Earth and Planetary Science Letters 135, 41-56. 
Tripsanas, E.K., Piper, D.J.W., 2008. Glaciogenic debris-flow deposits of Orphan Basin, offshore eastern Canada: Sedimentological and rheological properties, origin, and relationship to meltwater discharge. Journal of Sedimentary Research 78 (11/12), 724-744.

Wang, D., Hesse, R., 1996. Continental slope sedimentation adjacent to an ice margin. II. Glaciomarine depositional facies on the Labrador Slope and glacial cycles. Marine Geology 135, $65-96$.

\section{Figure captions}

Fig. 1 Late Pleistocene Bond cycles with superposed millenial-scale Dansgaard-Oeschger (D-O) oscillations showing gradual cooling and their rapid termination by abrupt returns to warm interstadials (modified from Bond et al., 1993, fig3). YD - Younger Dryas event.

Fig. 2 Lithologic, paleontologic and paleomagnetic characteristics of Heinrich layers (after Grousset et al., 1993).

Fig. 3A. Characteristics of iceproximal core Hu97-048-09: Ice-rafted detritus (IRD, $>150 \mu \mathrm{m}$ fraction in \%), magnetic susceptibility (SI units), digital spectrophotometer data (L-parameter), detrital carbonate (\%), total organic carbon (TOC, \%) and $\delta^{18} \mathrm{O}(\%)$. Analyses for DC, TOC and Oisotopes were done at $2.5 \mathrm{~cm}$ intervals between 300 and 560 and 750 and $870 \mathrm{~cm}$ subbottom. The high peaks in IRD (at $475 \mathrm{~cm}$ ) and magnetic susceptibility (at 475 and $500 \mathrm{~cm}$ ) are due to large pebbles. Radiocarbon dates are reported in C-14 years with a reservoir correction. The gap between 8.6 and 9 mbsf is due to a correction made during reinspection of the working half of the core. A: redrafted from Rashid et al. (2003a). B. Correlation of H-layers in Labrador cores MD95-24 
(Orphan Knoll), Hu90-13-29 (Labrador Rise) and and DSDP Site 609 with the Greenland ice core GISP2. $\mathrm{k}_{\mathrm{ARM}} / \mathrm{k}(\mathrm{SI})=$ anhysteretic remanent magnetization/magnetic susceptibility ratio. $N p l(\%)$ in DSDP 609: Neogloboquadrina pachyderma (sinistral). Data for Hu90-13-29 from Rashid et al. 2003b, for MD95-24 from Stoner et al. (2000), for DSDP Site 609 from Bond et al. (1993) and for the GISP2 ice core from Stuiver and Grootes (2000) and Grootes and Stuiver (1997). For core locations of Figure 3 see Figure 6.

Fig. 4A, B. Thickness variation of H-layers 1 and 2 (from Hesse and Khodabakhsh, 1998, Fig.1).

Fig. 5A-F. Isopach maps of H-layers $0,1,2,3,4$ and 5 in iceproximal areas of the Labrador Sea based on McGill core collection. (see text for details);

Fig. 6. Locations of all cores used in this study.

Fig. 7A Correlation of ash zone AZ-I and ash layers AL-1 to -5 in eight piston cores from the Labrador Sea. ${ }^{14} \mathrm{C}$ ages (not corrected for reservoir age) are from Wang and Hesse (1996) for cores H90-13-26 and -29 and Hesse (1995b) for cores H87-25-7 and -9. B Late Pleistocene ash stratigraphy in North Atlantic according to different authors. . Age scale is in C-14 years uncorrected for reservoir effects.

Fig. 8. X-radiographs of 1-cm thin sediment slabs. I) Type I H-layer: massive ice-rafted sediment on upper slope; core 90-13-33, 612-634 cm. II) Type-II H-layer: Lofted sediment: stacked graded mud layers with ice-rafted debris; core H90-13-26, 240-260 cm. III) Type-III H-layer: Thin carbonate-rich mud turbidites alternating with laminae of IRD; core H90-13-34, 255-275 cm. Note 
gravel-sized dropstone. IV) Type-IV H-layer: Layers of ice-rafted debris interbedded with thin mud-turbidites; core H87-25-2, 57-77 cm. V) Type-V H-layer: Bioturbated, detrital-carbonate rich hemipelagic sediment with IRD; core H88-24-7, 183-203 cm. For detailed interpretations see text.

Fig. 9. Print of $X$-radiographs made from $1 \mathrm{~cm}$ thick sediment slab of lofted sediment (Heinrich layer type II) in core Hu92-45-05 showing dozens of graded mud layers containing IRD together with grain-size frequency histograms for one of the mud layers (compare with Fig. 11 for complete view of H-layer 1 in this core). The darker basal parts of the graded layers are fine silt that grade upward into silty clay which is lighter colored because of lower density. The radiograph starts at the base of Heinrich Event 1 (at $160 \mathrm{cmbsf}=\mathrm{cm}$ below sea floor). $\mathrm{Md}=$ median diameter in $\varphi$ units. Note grading indicated by upward increase in Md. From Hesse and Khodabakhsh (2006, fig.3).

Fig. 10. Histograms of grain-size distributions. A) H-layer Type II: Lofted sediment deposit; core 90-13-26, 33-35 cm (from Wang and Hesse, 1996, fig. 8c). B) HL Type IV. C) HL Type III; core Hu87-25-2, cm 55-57 (from Wang and Hesse 1996, fig.8e). D) Mud turbidite; core Hu92-45-1, 207-209 cm (from Khodabakhsh 1997, p. 230) .

Fig. 11A. Comparison of organic carbon concentrations in various sedimentary facies between Labrador slope and basin (NAMOC levees). From Khodabakhsh 1997, fig. 4.7. B. Organic carbon concentrations in various types of H-layers.

Fig. 12A Concentration of IRD (weight $\%$ of $>125 \mu \mathrm{m}$ fraction), organic carbon weight $\%$, hydrogen index (HI) and oxygen index (OI) for slope core 90-13-26 (from Khodabakhsh 1997, fig. 4.9). B. 
Classification of organic matter based on hydrogen index (HI) versus oxygen index (OI) for core Hu90-13-26 (from Khodabakhsh 1997, fig. 4.11). Most samples are type III kerogen. Most of the samples are immature. L - lofted facies (= type-II HLs); HI - hemipelagic sediment with IRD (if encountered in HLs = type-V HL); H - hemipelagic sediment; T - fine-grained spill-over turbidite; D - debris-flow deposit; C - contourite.

Fig. 13. Oxygen-isotope profiles of Labrador Sea piston cores Hu90-29, MD95-22,-24,-25 compared to Late Pleistocene Marine Oxygen Isotope Stages of the GISP 2 Greenland ice core. The piston-core isotope profiles show lowering of the $\delta^{18} \mathrm{O}$ values of the planktonic foraminifera Neogloboquadrina pachyderma (sinistral) in sediments during Heinrich events (modified from fig. 4 of Rashid et al., 2003a). Note that the vertical scale on GISP2 is in calendar years BP while sediment cores are plotted against cm subbottom depth. TWR - trigger weight core.

Fig. 14 Distribution of H-layers 1 to 4 in the Labrador Sea. Note the predominance of type-II Hlayers in slope and rise cores close to the Hudson Strait outlet, the occurrence of types III and IV where the flow paths of spill-over turbidity currents from the slope canyons and NAMOC, respectively, lie under the iceberg drift route, and type $\mathrm{V}$ in distal regions. Also note the different distribution pattern for H-layer 3 and the paucity of cores containing H-layers 3 and 4. Depths contours in km. Modified from Khodabakhsh (1997, fig. 6.5).

Fig. 15 Turbid surface plumes, interflows, turbidity currents and loftng sediment columns from fresh-water generated turbidity currents at ice-stream terminations (from Hesse and Khodabakhsh 2006, fig. 1). 
Fig. 16 Lithofacies map of the northern and central Labrador Sea. NA, NC, NBA - main branches of NAMOC labeled counterclockwise and in hierarchical order; the same labeling scheme applies to tributaries D, E, etc. (from Hesse and Khodabakhsh, 2006, fig.2).

Fig. 17. Comparison of sediment structure, foram content and grain size of ice-rafted hemipelagic sediment and debris-flow deposits in upper slope core Hu92-045-02 (from Khodabakhsh, 1997, fig. 3.8). Numbers $1-6$ denote position of grain-size samples.

Fig. 18. Comparison of textural characteristics and foram content between hemipelagic sediment with ice-rafted debris (facies HI) and debris-flow deposits (facies D) in slope cores Hu90-013-26, 29 and $\mathrm{Hu}$ 87-9 (from Khodabakhsh 1997, fig. 4.4).

Fig. 19 Plateau-like ridge between canyons NBABBD and NCABA showing continuous seismic reflectors spaced $<0.1 \mathrm{sec}$ two-way travel time apart that may represent ice-proximal H-layers. Vertical scale: two-way travel time.

Fig. 20. X-radiographs of Heinrich layer 5 in 7 piston cores from the Labrador Sea. Cores 90-26, $28,-29$ and 92-6 consist of type I.

Fig. 21 X-radiographs of Heinrich layer 5a in 3 piston cores from the Labrador Sea.

Fig. 22 Piston cores from the braidplain. A. Lithology and facies; B. ${ }^{18} \mathrm{O}$ stratigraphy (with AMS ${ }^{14} \mathrm{C}$ 
ages), $\delta^{13} \mathrm{C}$ values (with marine oxygen isotope stages (MIS) 1 to 4 ) for core 90-013-13 (modified from Hillaire-Marcel et al., 1994). C. $\delta^{18} \mathrm{O}$ and $\delta^{13} \mathrm{C}$ values and AMS ${ }^{14} \mathrm{C}$ ages based on $N$. pachyderma (s) for cores 84-030-8, 9, and 16. Modified from Hesse et al. (2001, fig. 3). The absence of H-layers except in core 84-033-07 is probably due to the fact that turbidite deposition on the sandy braidplain continued to or beyond the Younger Dryas event. The ages $>15 \mathrm{ka}$ of the hemipelagic sediment immediately overlying the turbidites are probably caused by bioturbation having admixed turbiditic mud to the hemipelagic sediment.

Table 1 Ages of H-layers 0 to 6 (modified from Rashid et al. 2003b, table 3).

Table 2 Chemical composition of ash fragments (from Khodabakhsh, 1997, table 4.3).

Table 3 Carbonate concentration in coarse and fine fractions of Heinrich layer types and other various depositional facies in Labrador slope and basin cores (from Khodabakhsh, 1997, table 4.2).

Table 4 Sediment distribution in modern icebergs (from Khodabakhsh, 1997, table 6.1). 


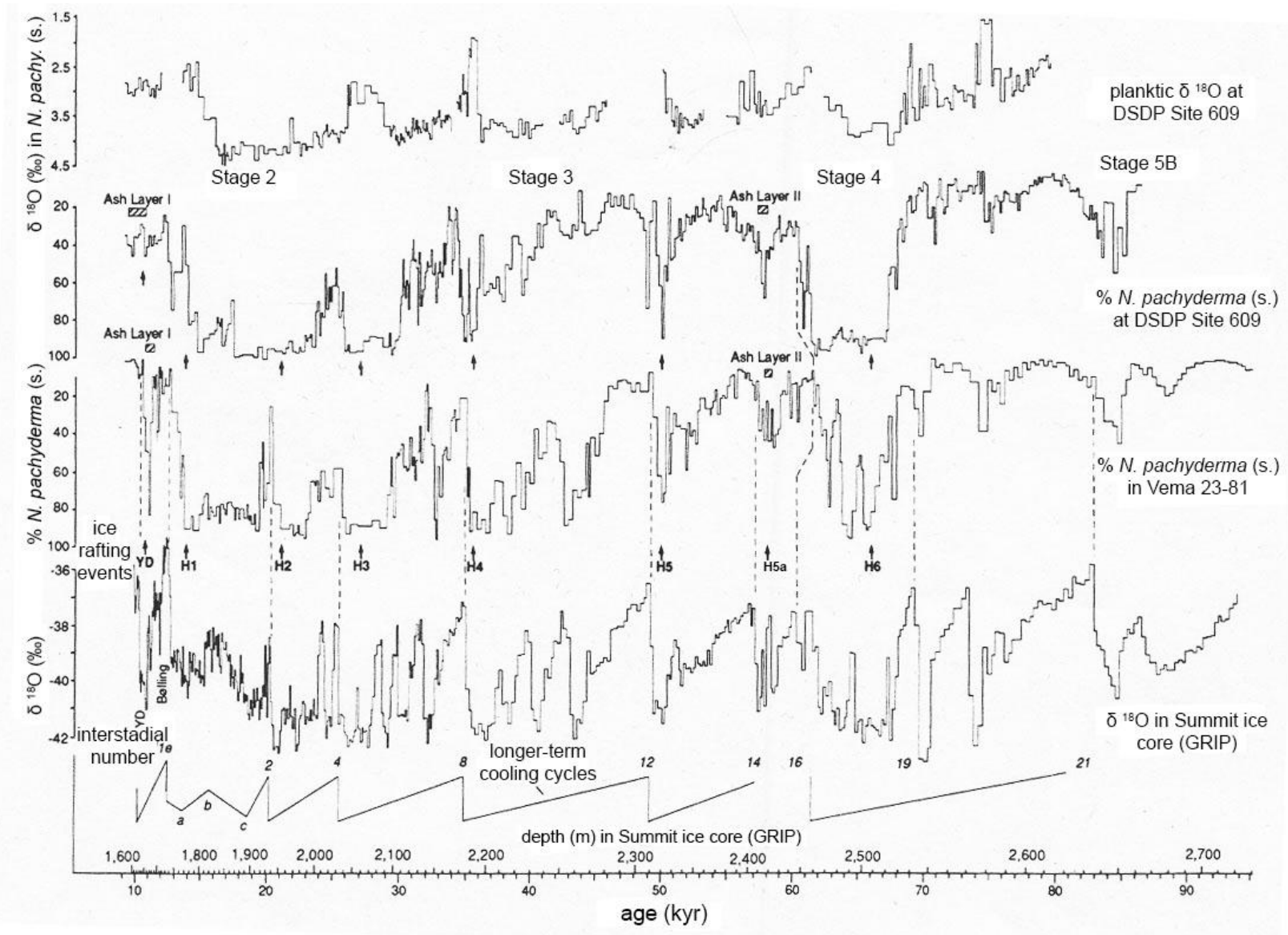

Fig. 1
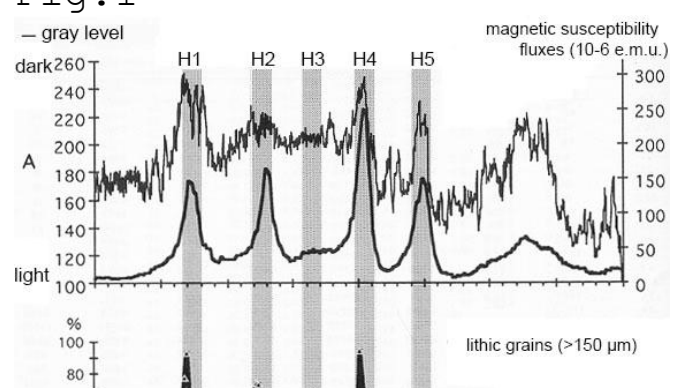

.

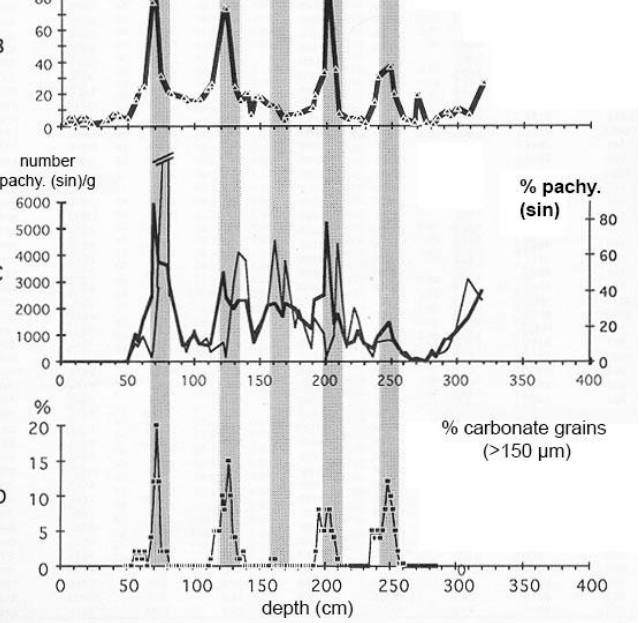


Fig. 2

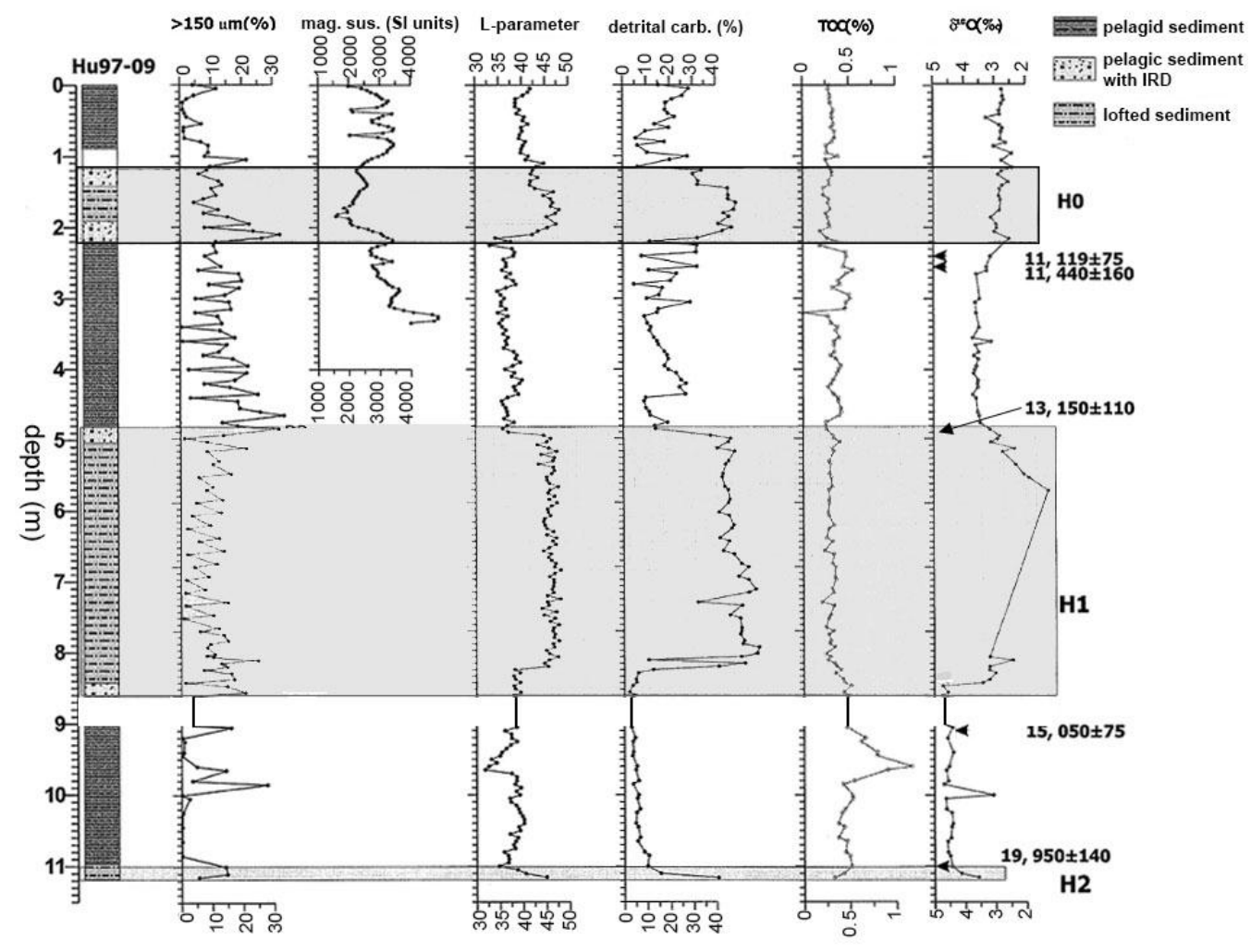

Fig. 3A 


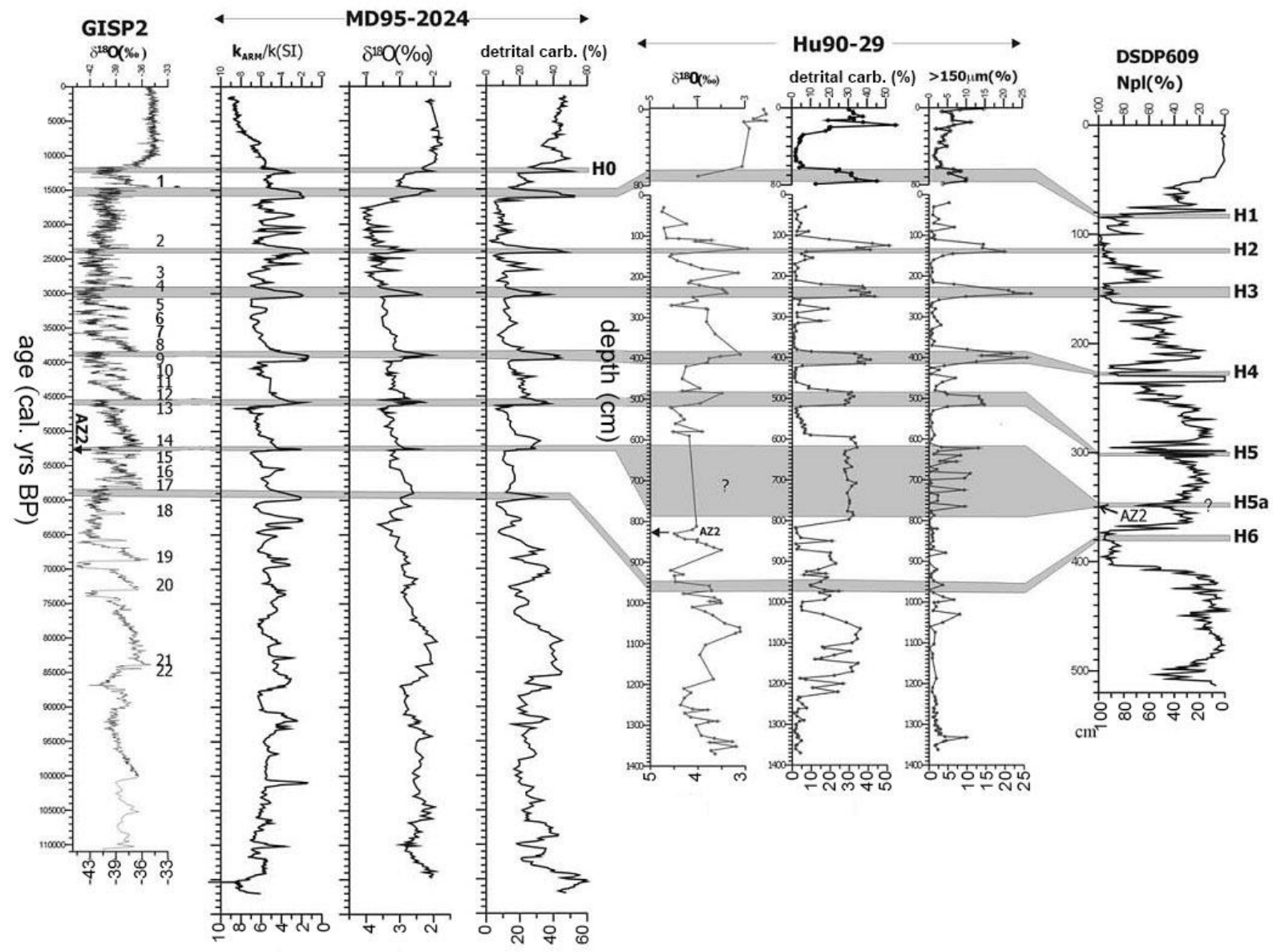

Fig. 3B

A

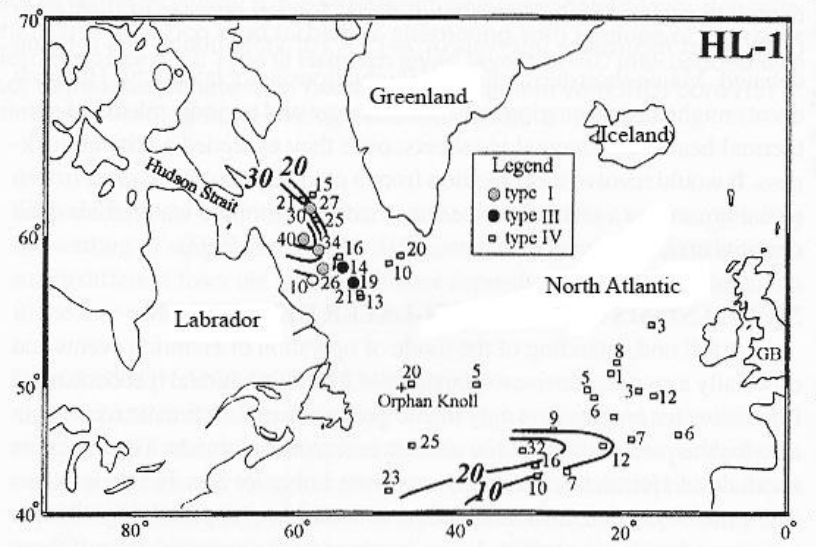

B

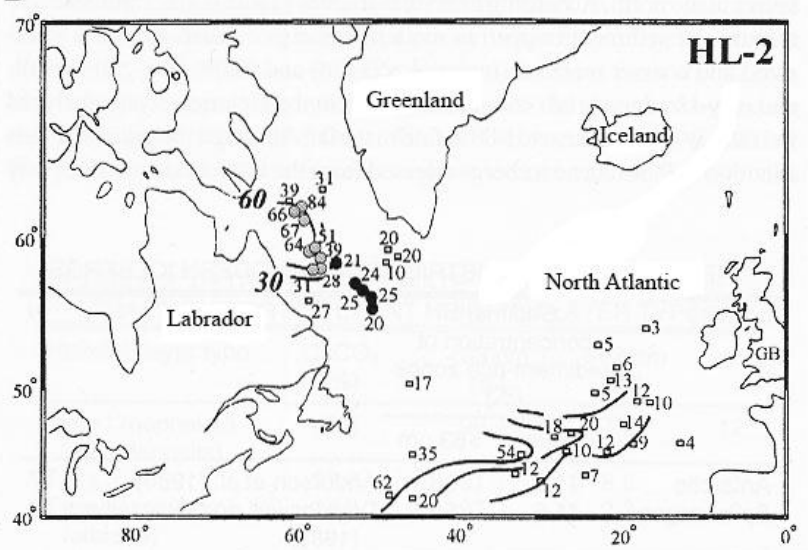

Fig 4 A, B 

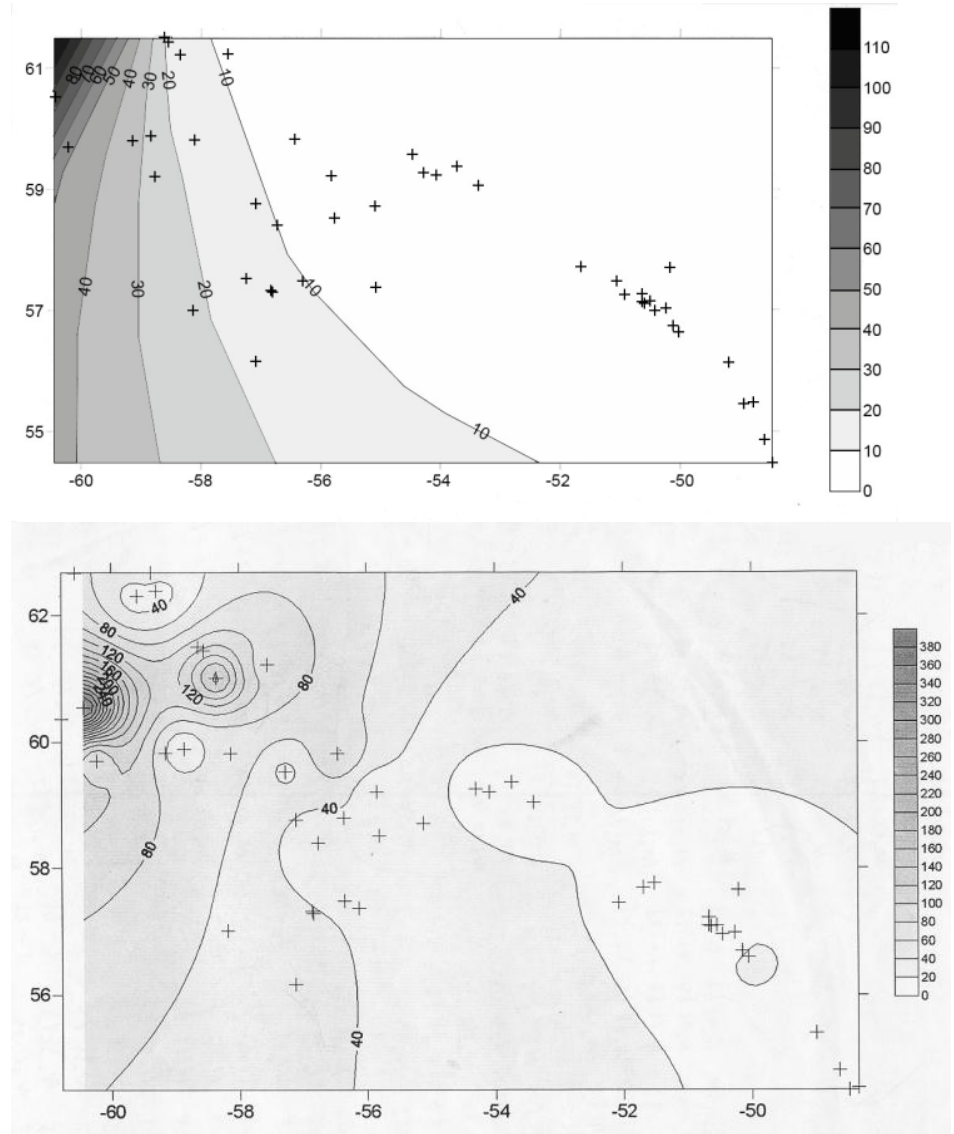

Fig 5A ( $\mathrm{HO})$

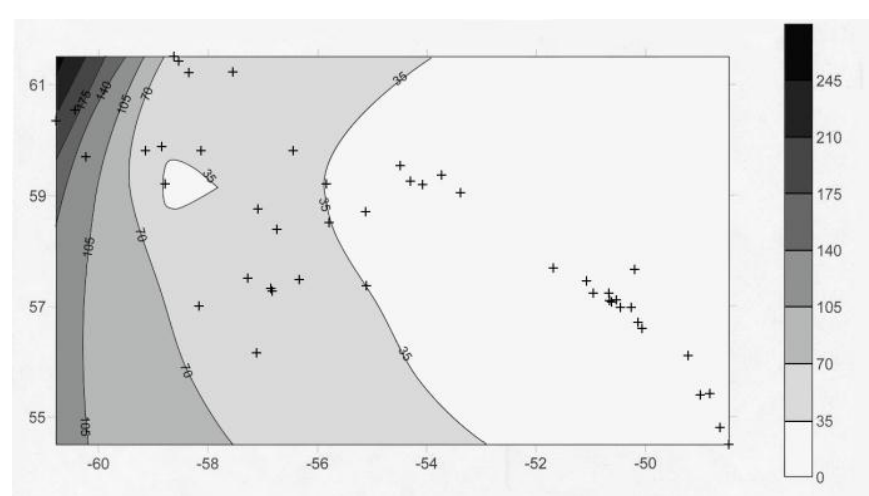

Fig 5B (H1) 


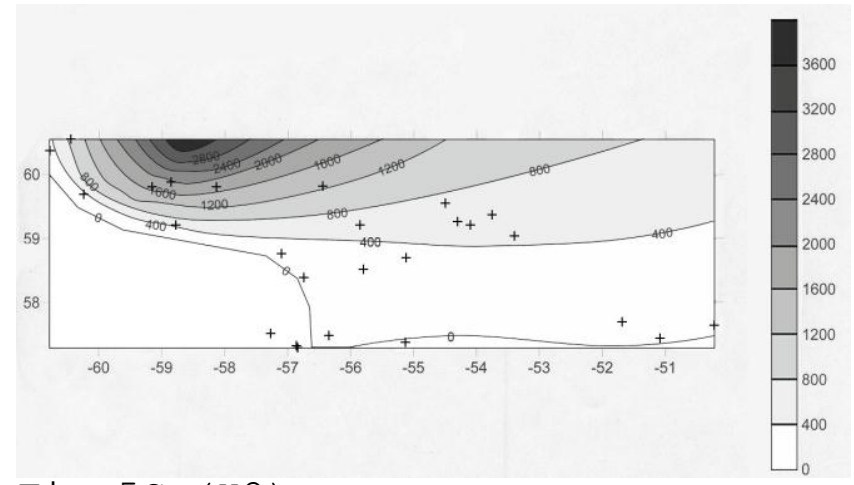

Fig 5C (H2)

Fig 5D (H3)
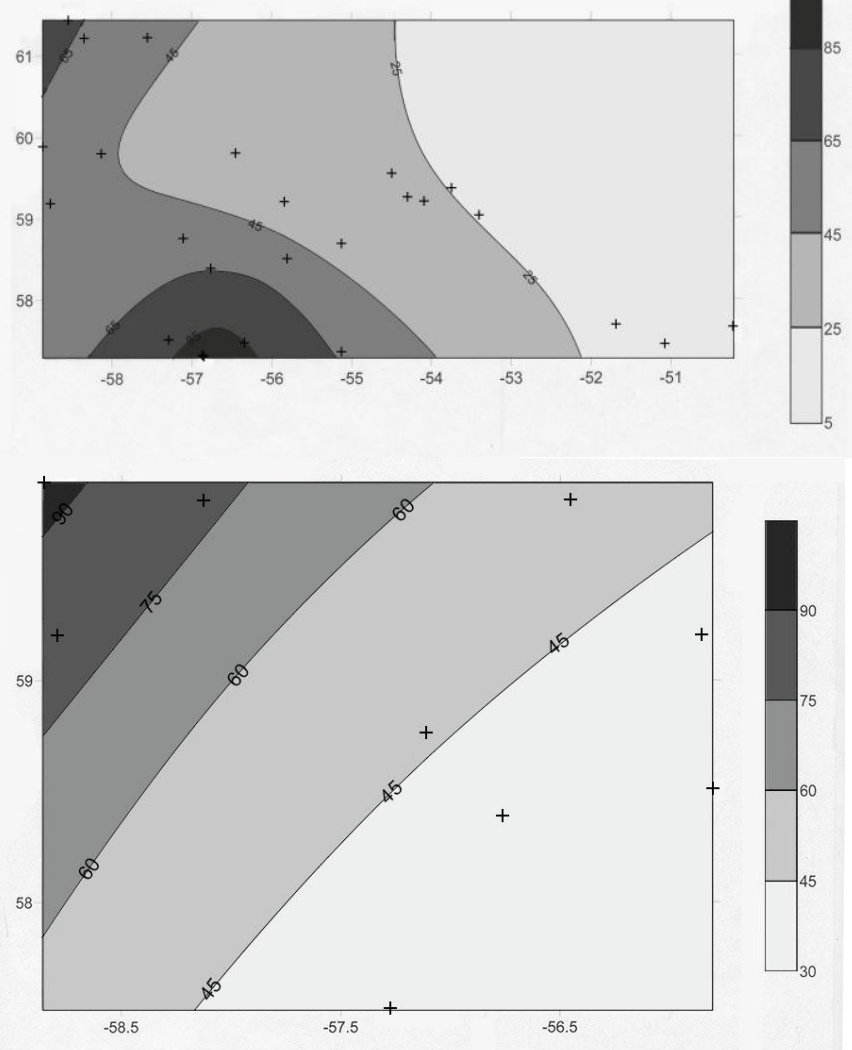

Fig 5E (H4)

Fig 5F (H5) 


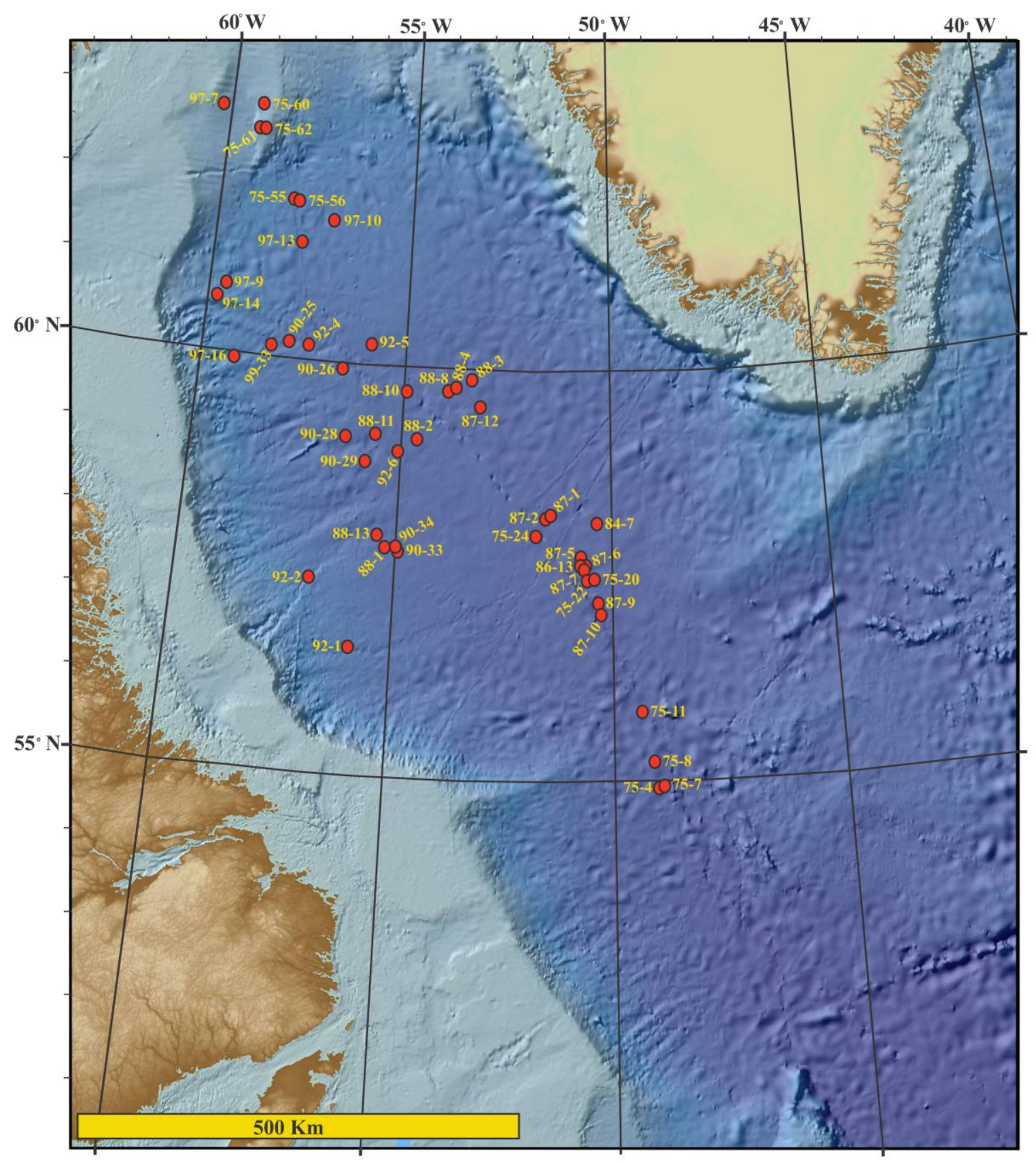

Fig. 6 

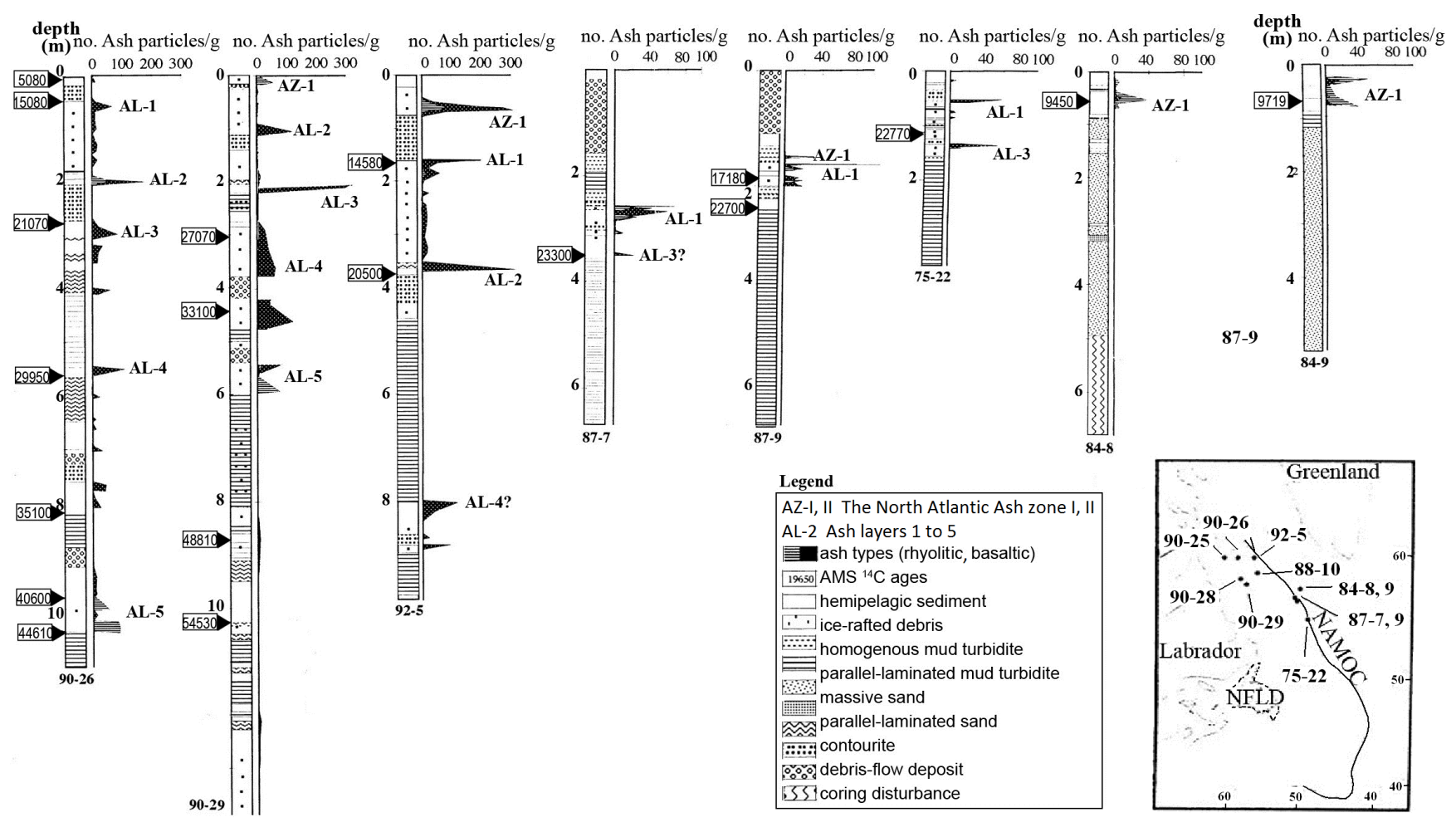

Fig. 7A

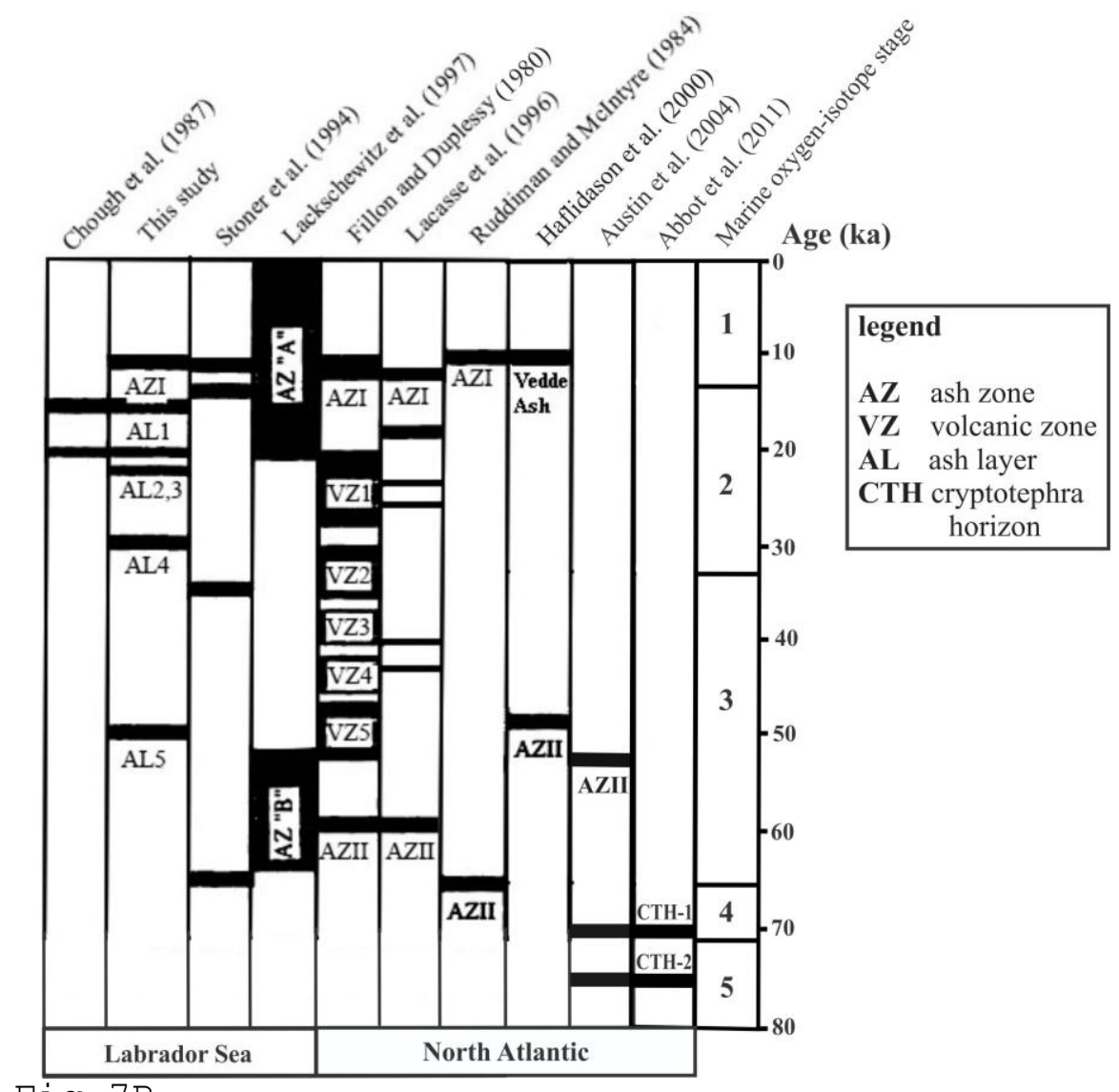



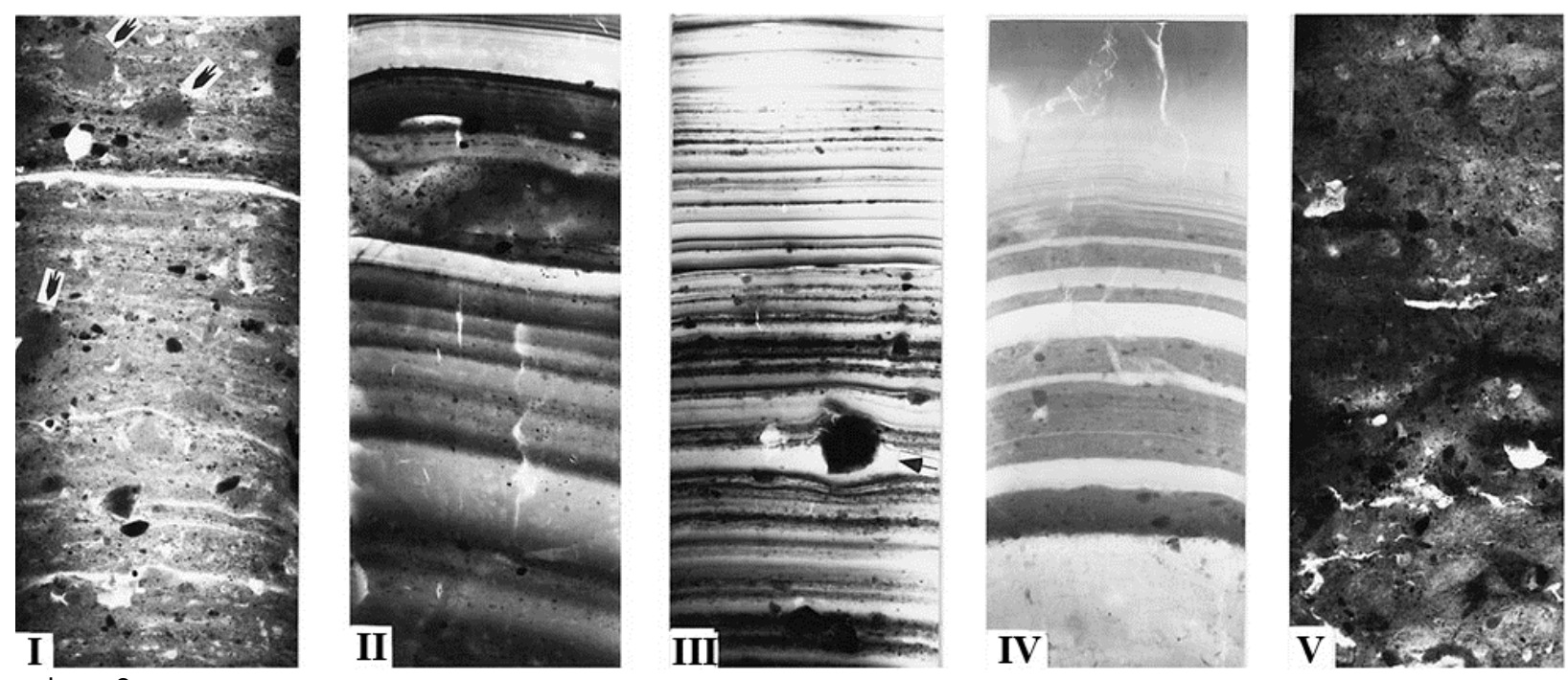

Fig 8 


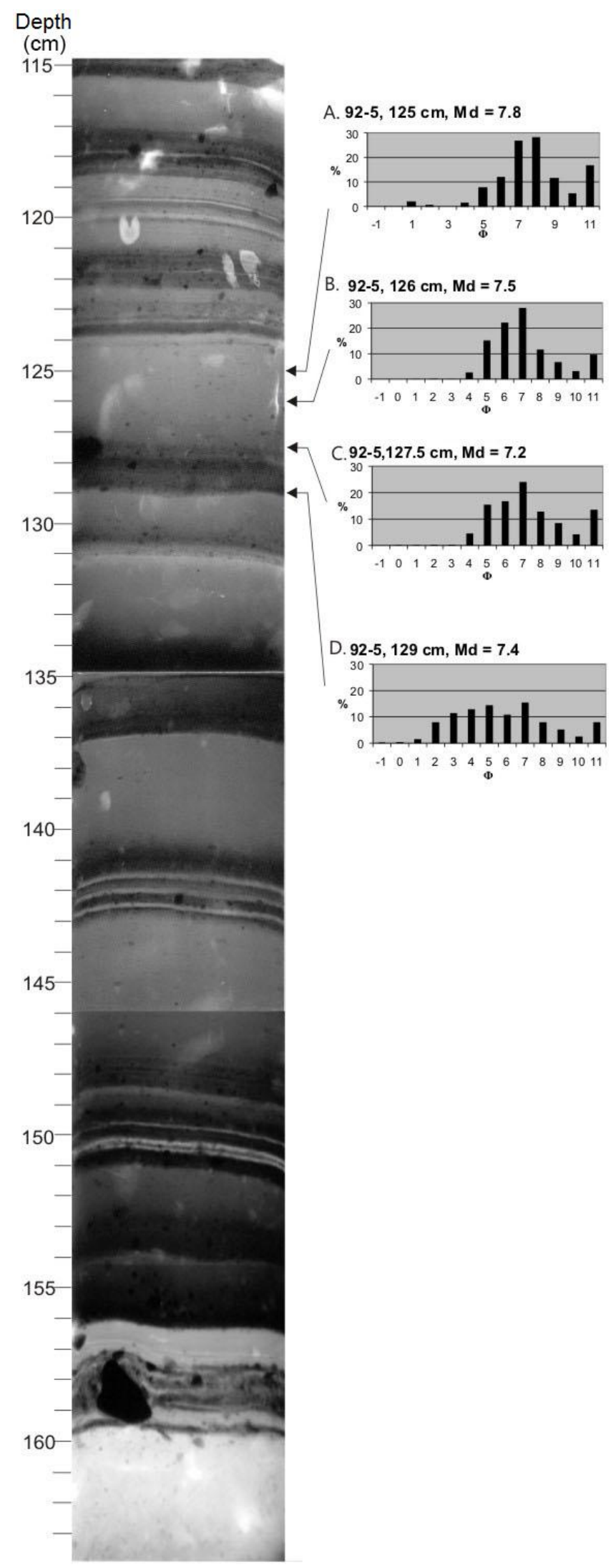

Fig 9 


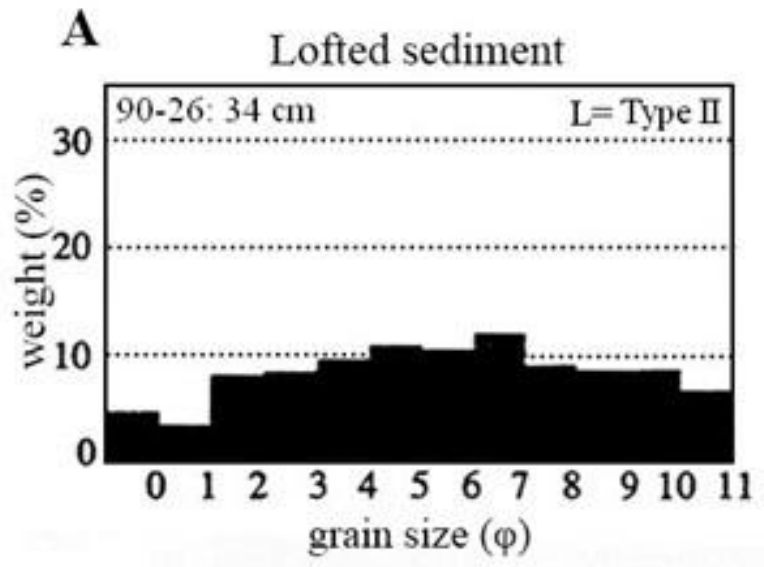

C

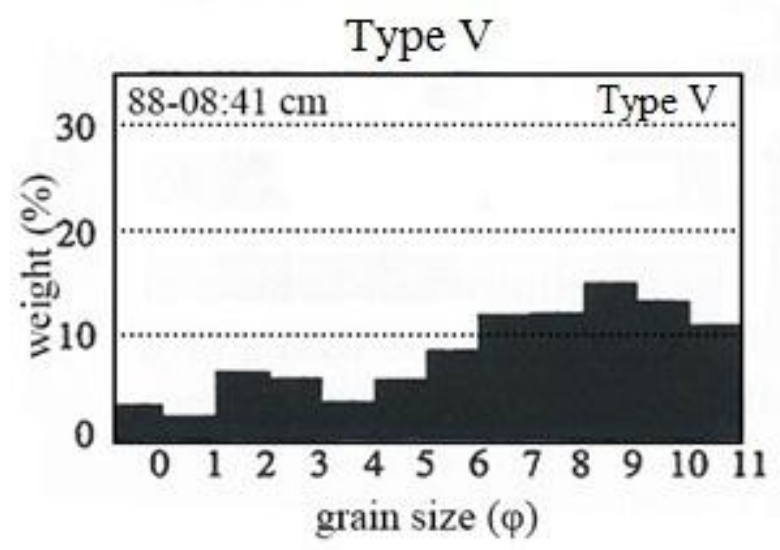

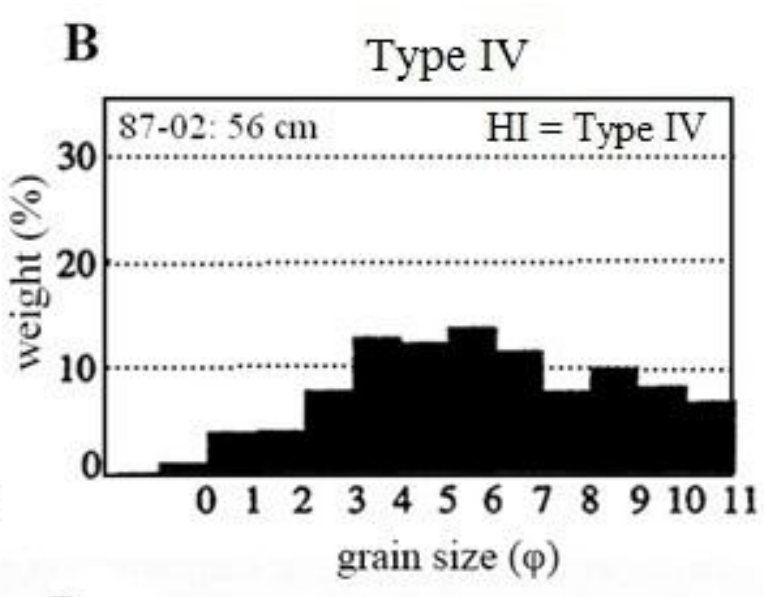

D

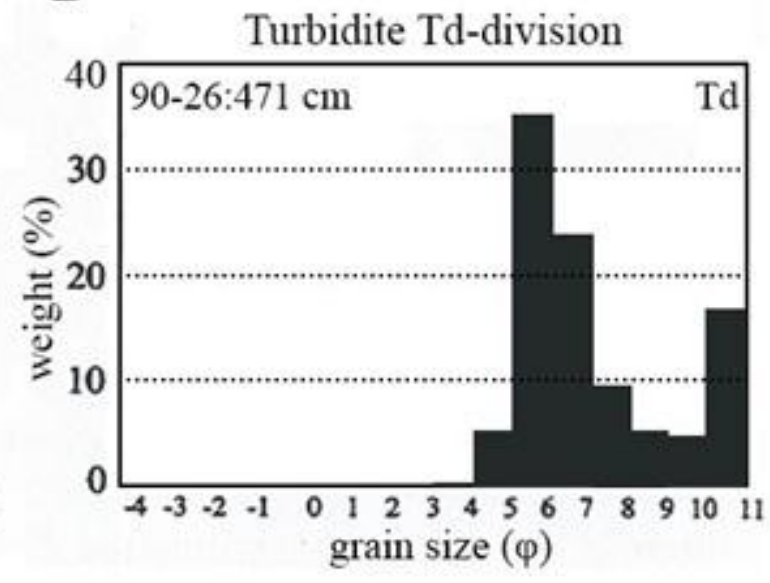

Fig. 10 


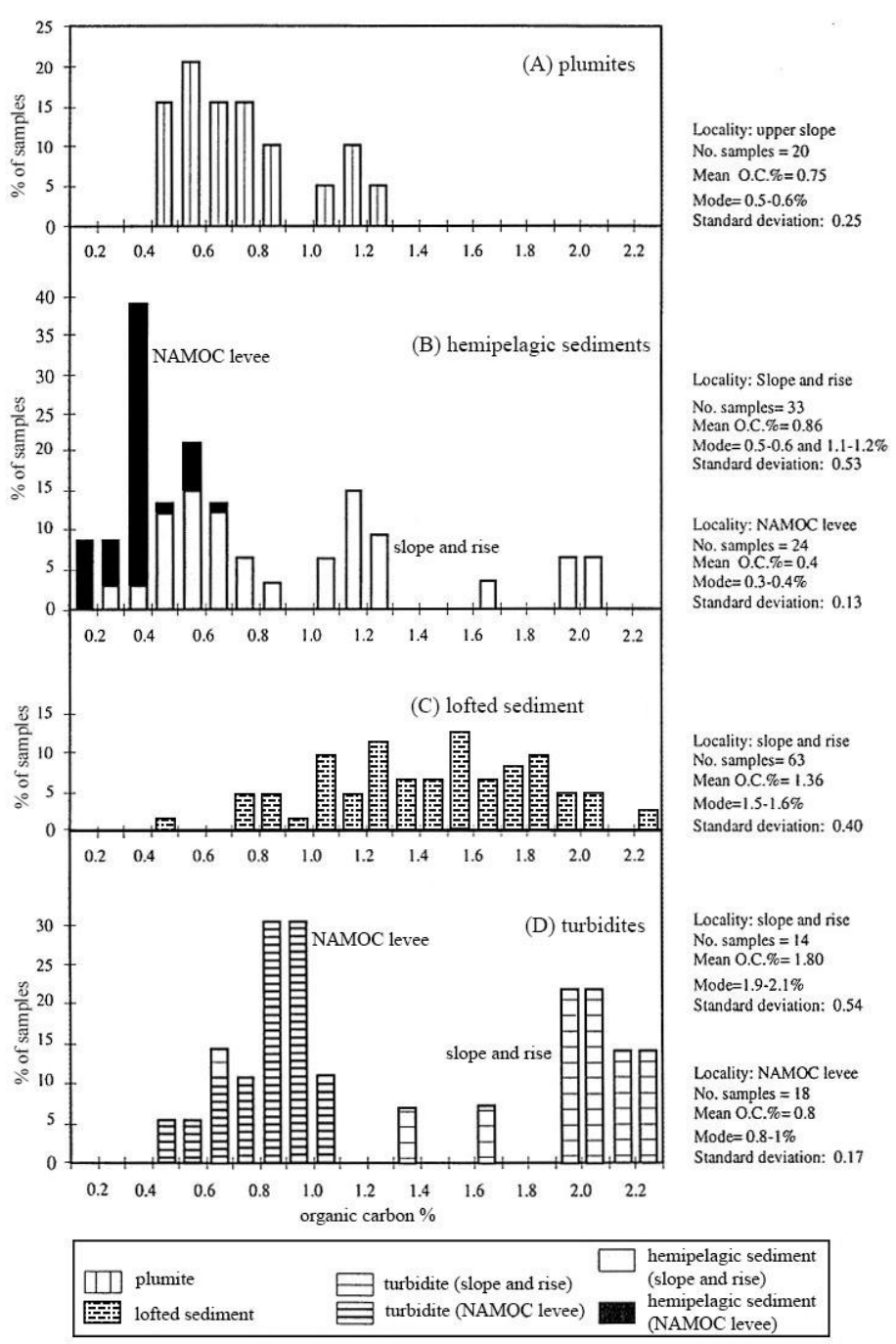




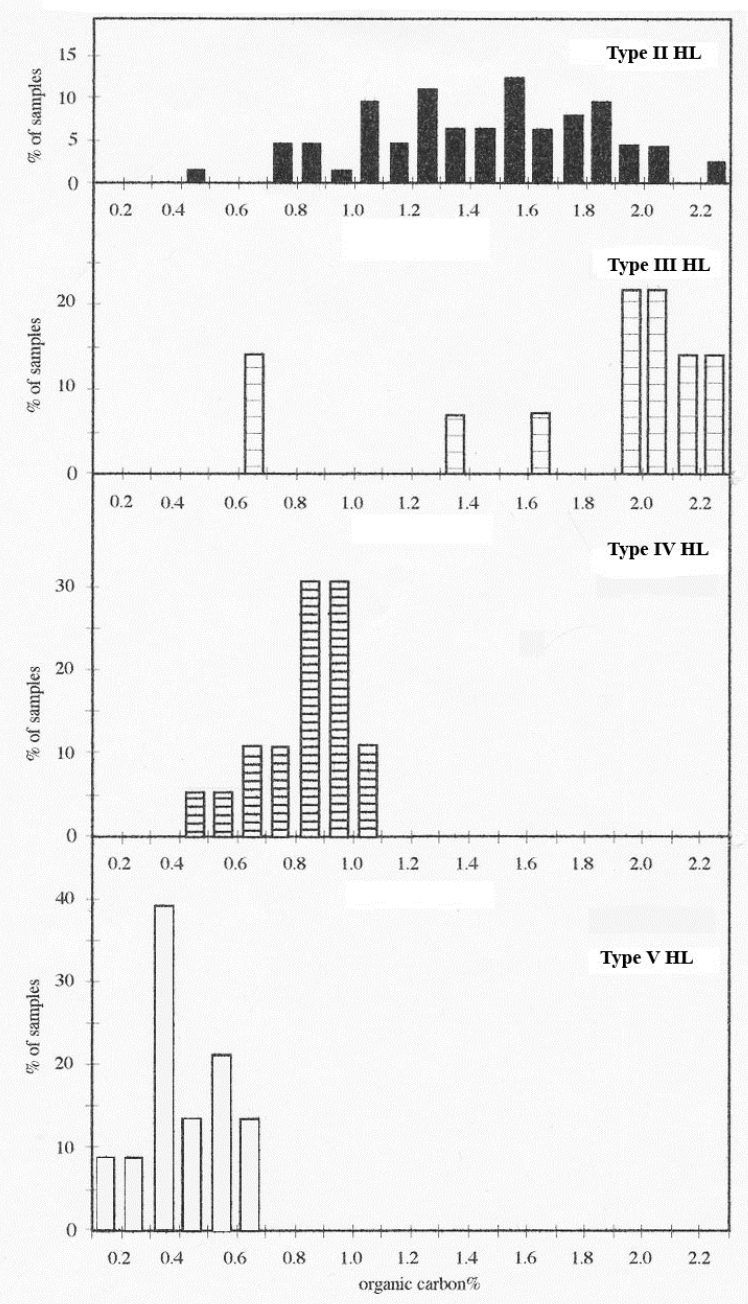

Fig 11A

Fig 11B 


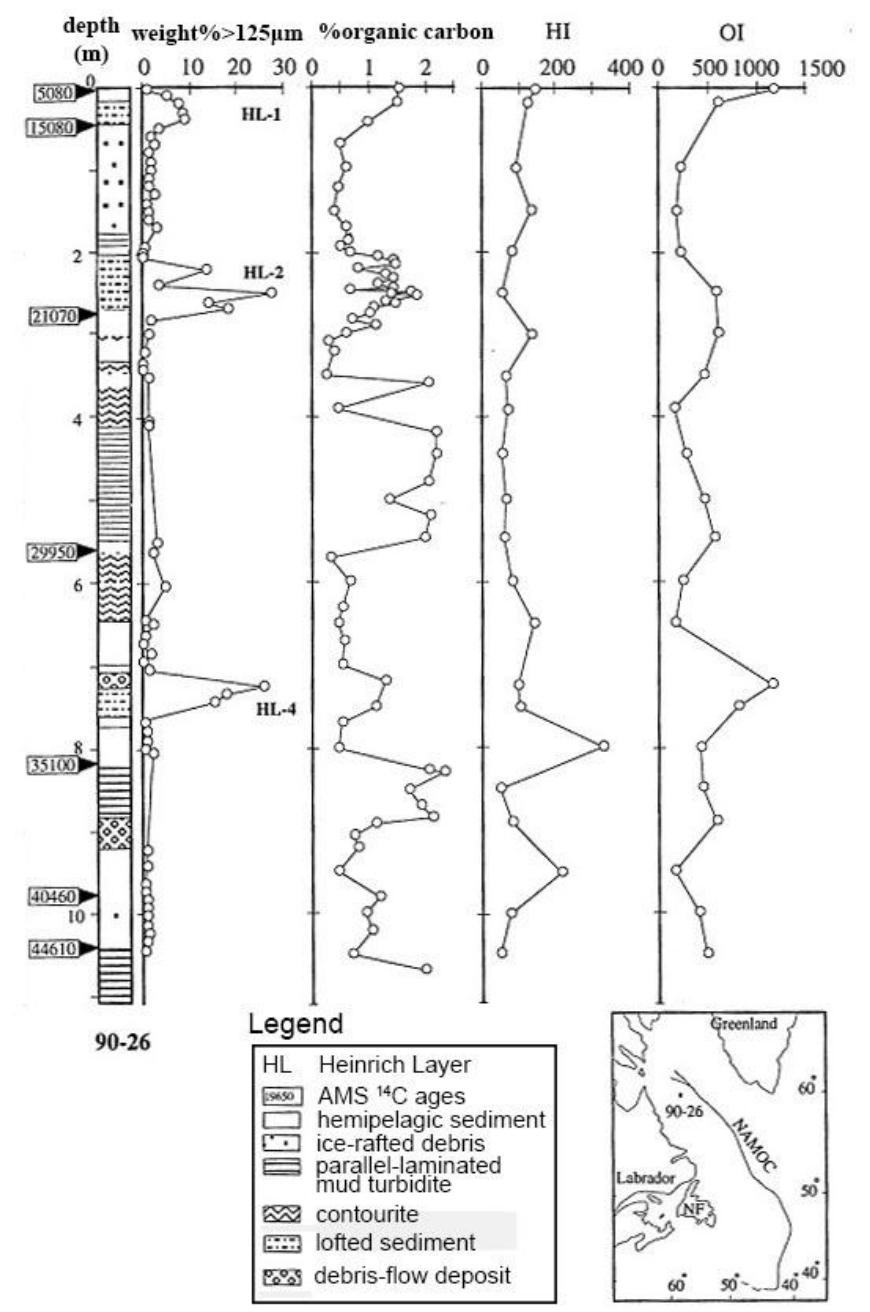

Fig 12A

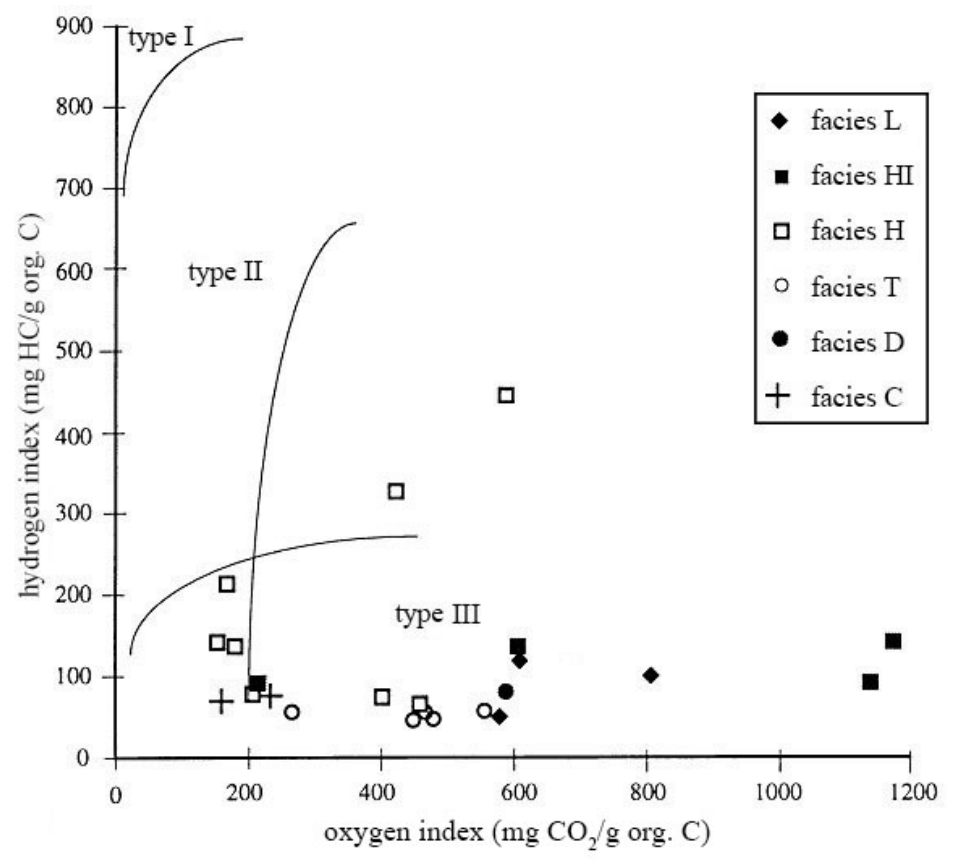


Fig 12B

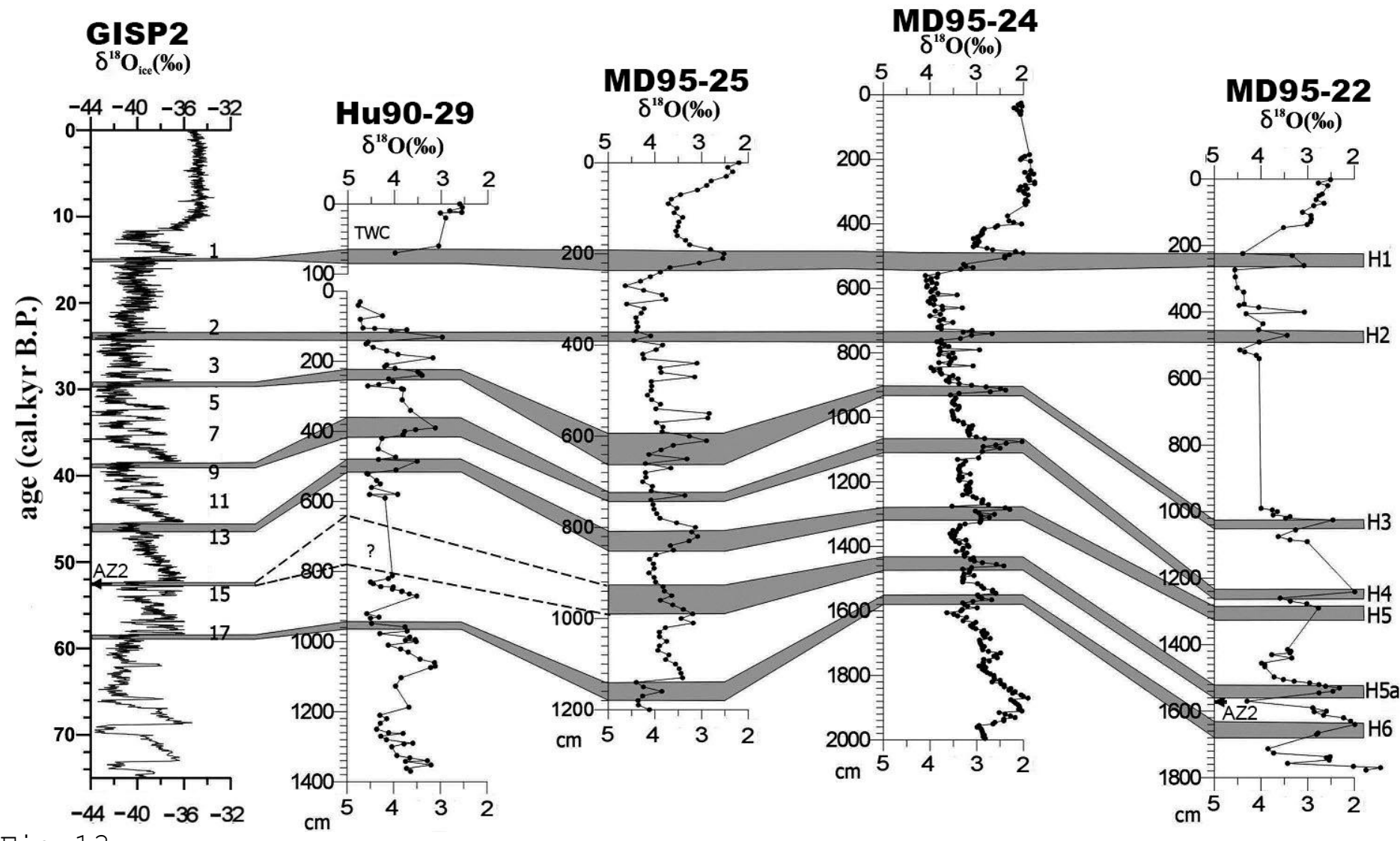

Fig 13 
HL-1

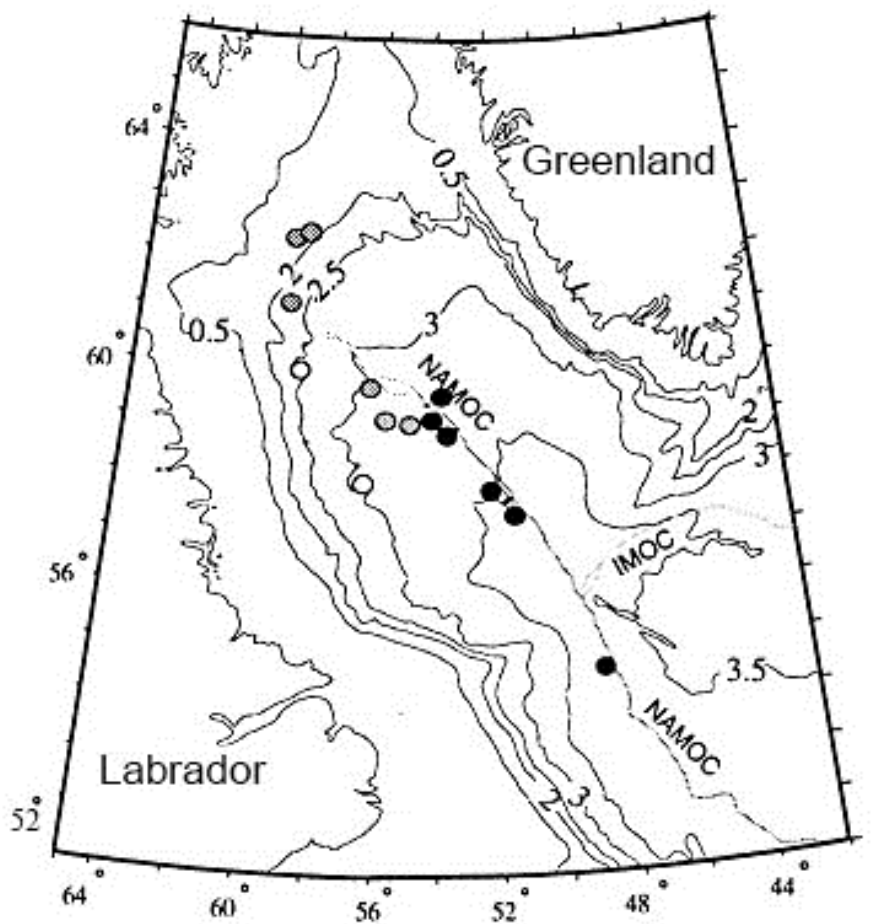

HL-2

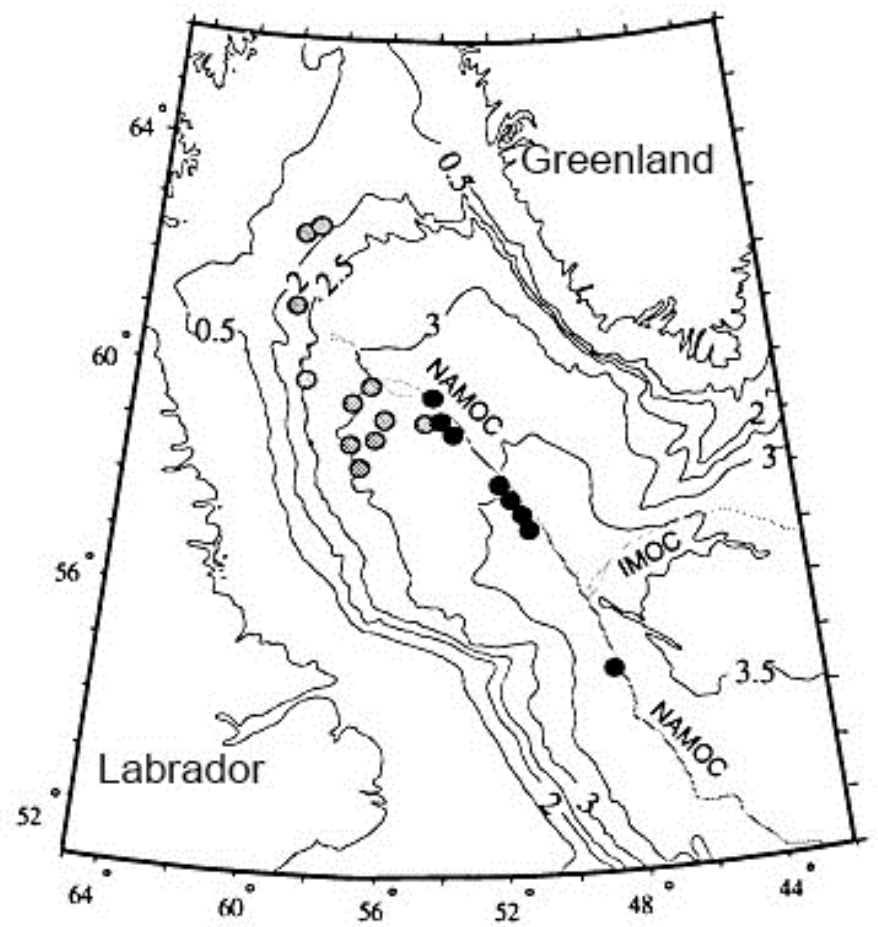

types of Heinrich layers

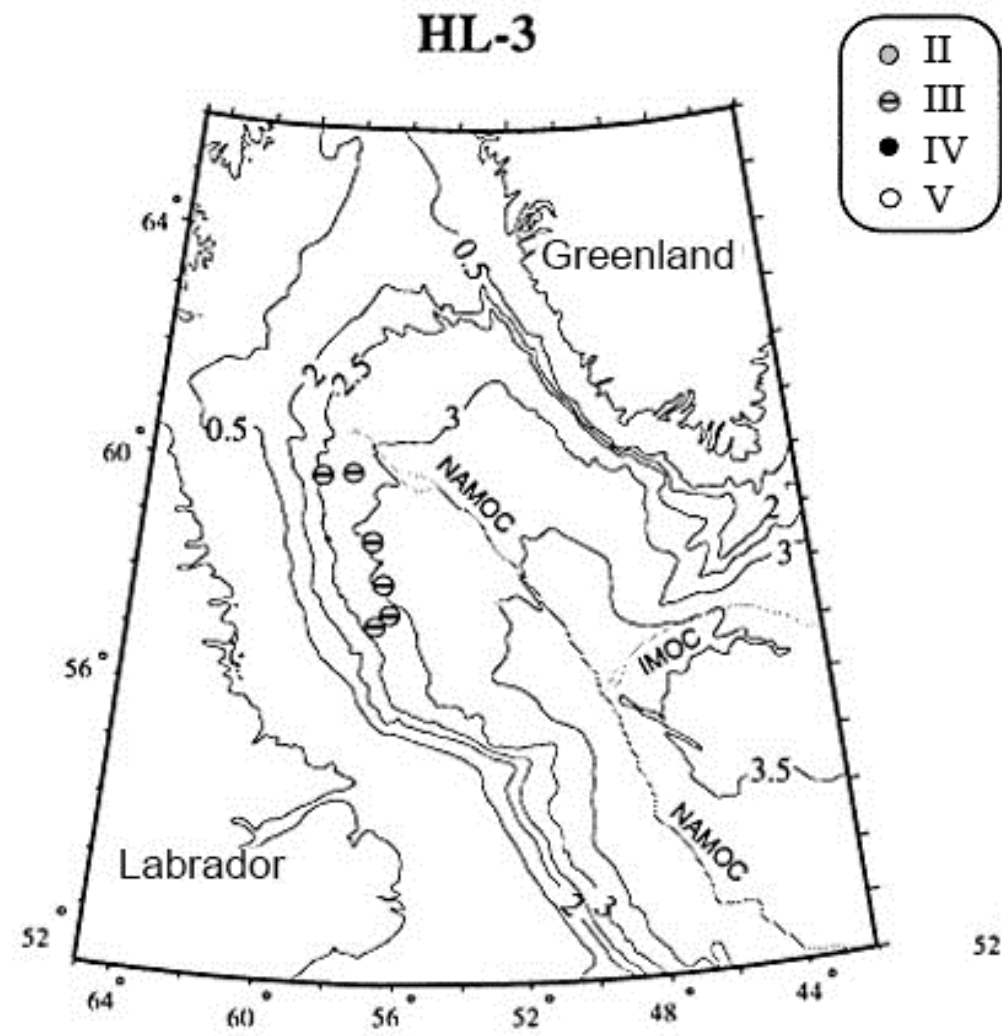

HL-4

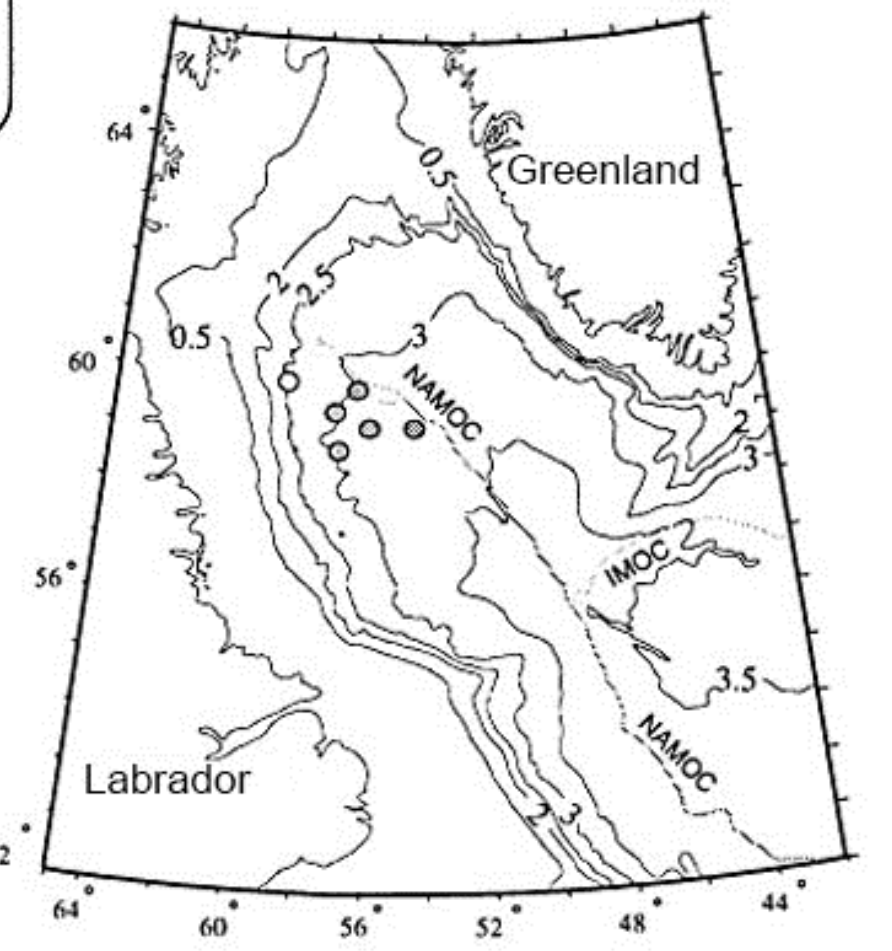


Fig 14

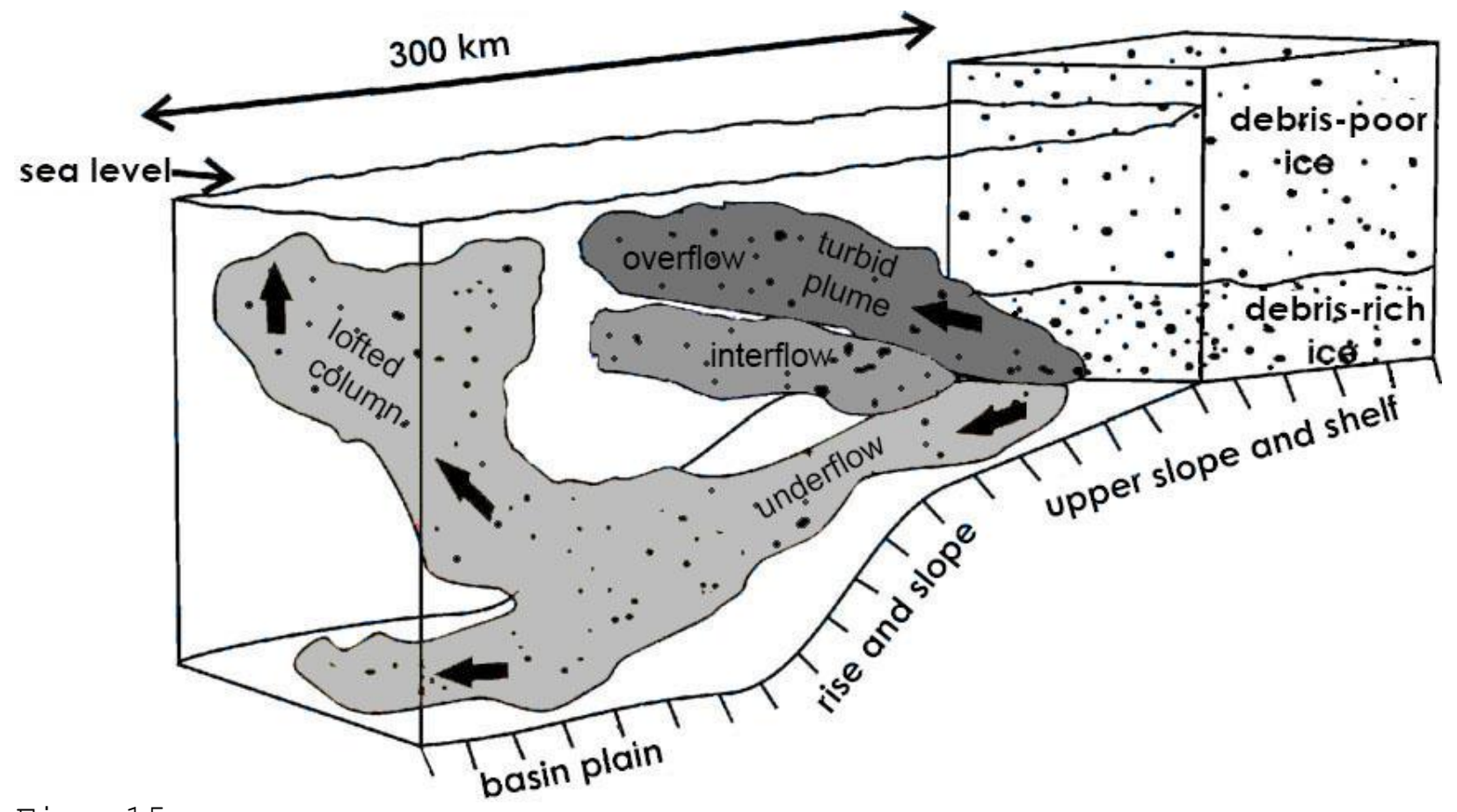

Fig. 15 


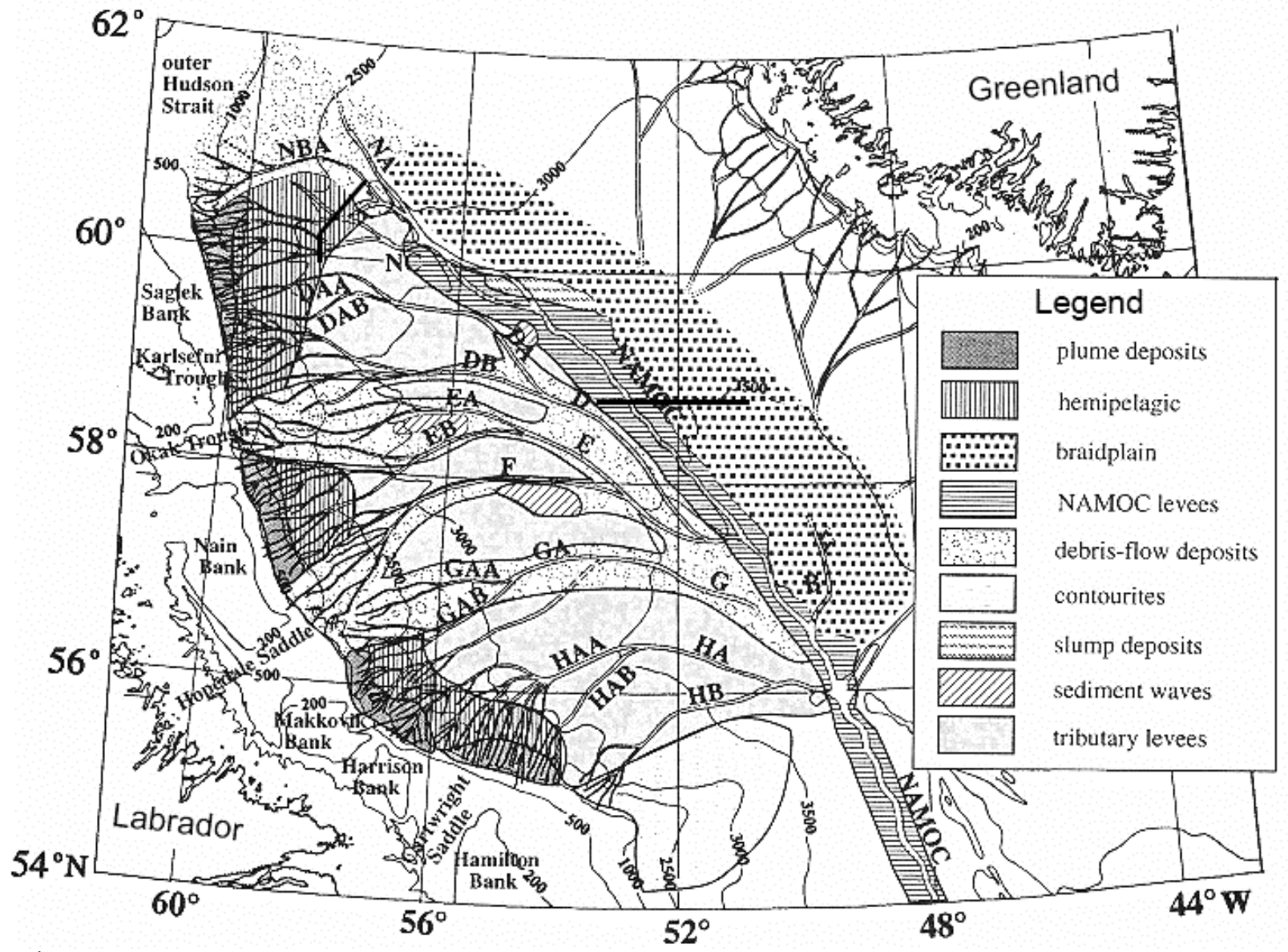

Fig 16 


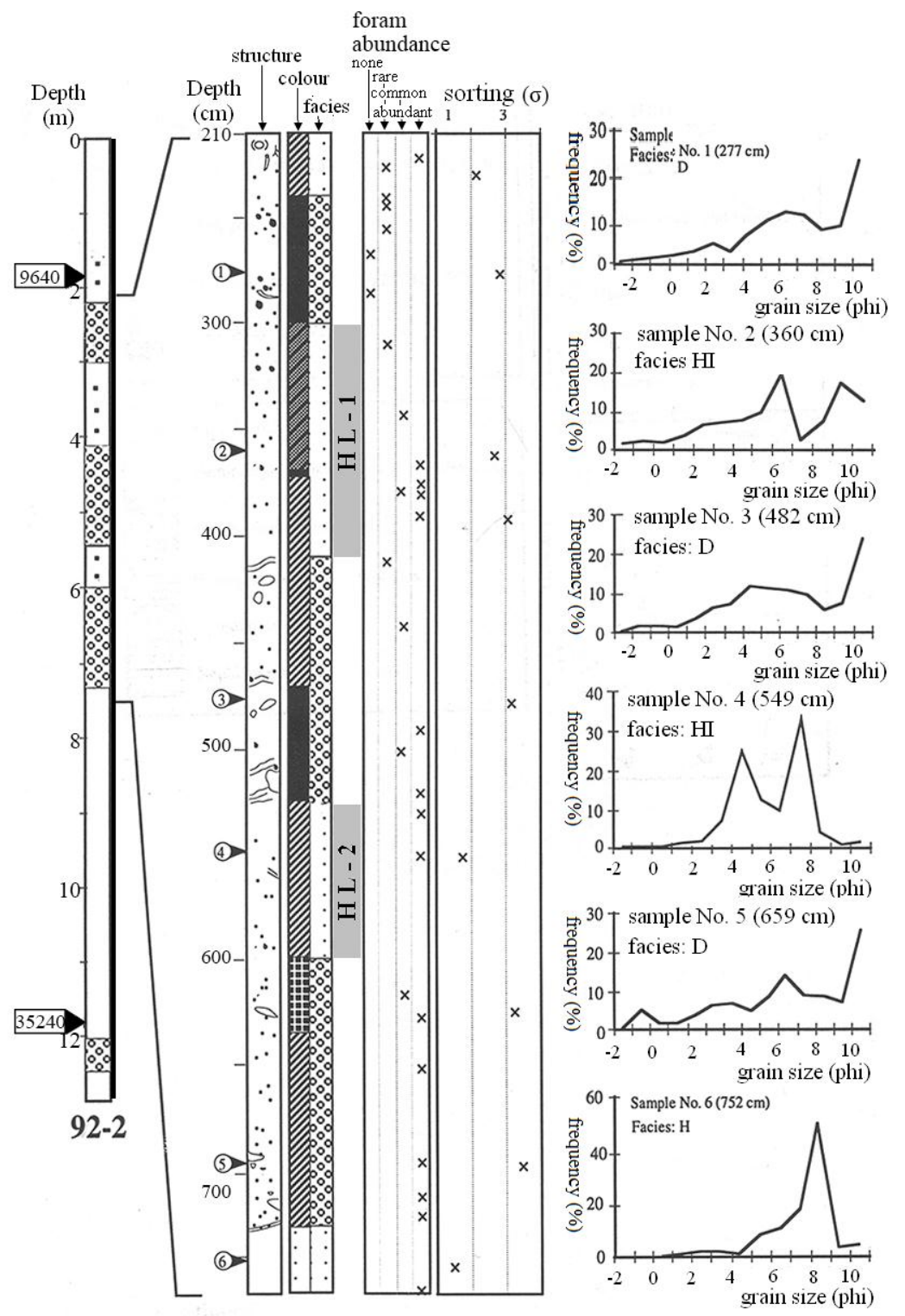




\section{Legend}

Sediment colour

\begin{tabular}{|c|c|}
\hline \multicolumn{2}{|c|}{ Sediment structure } \\
\hline$\left(\begin{array}{l}(0) \\
s, D^{k}\end{array}\right.$ & Bioturbation \\
\hline$F$ & Irregular bands and laminae \\
\hline$\bullet$ & Pebbles \\
\hline 00 & Mud clasts \\
\hline$\equiv$ & Irregular wavy lamination \\
\hline 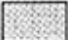 & Winnowed sitts \\
\hline
\end{tabular}

Fig. 17

Sediment facies
Hemipelagic sediments with/without IRD
Lomogenous mud turbidites
Lontourites

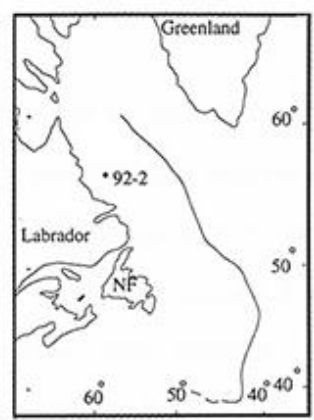

Fig.

18

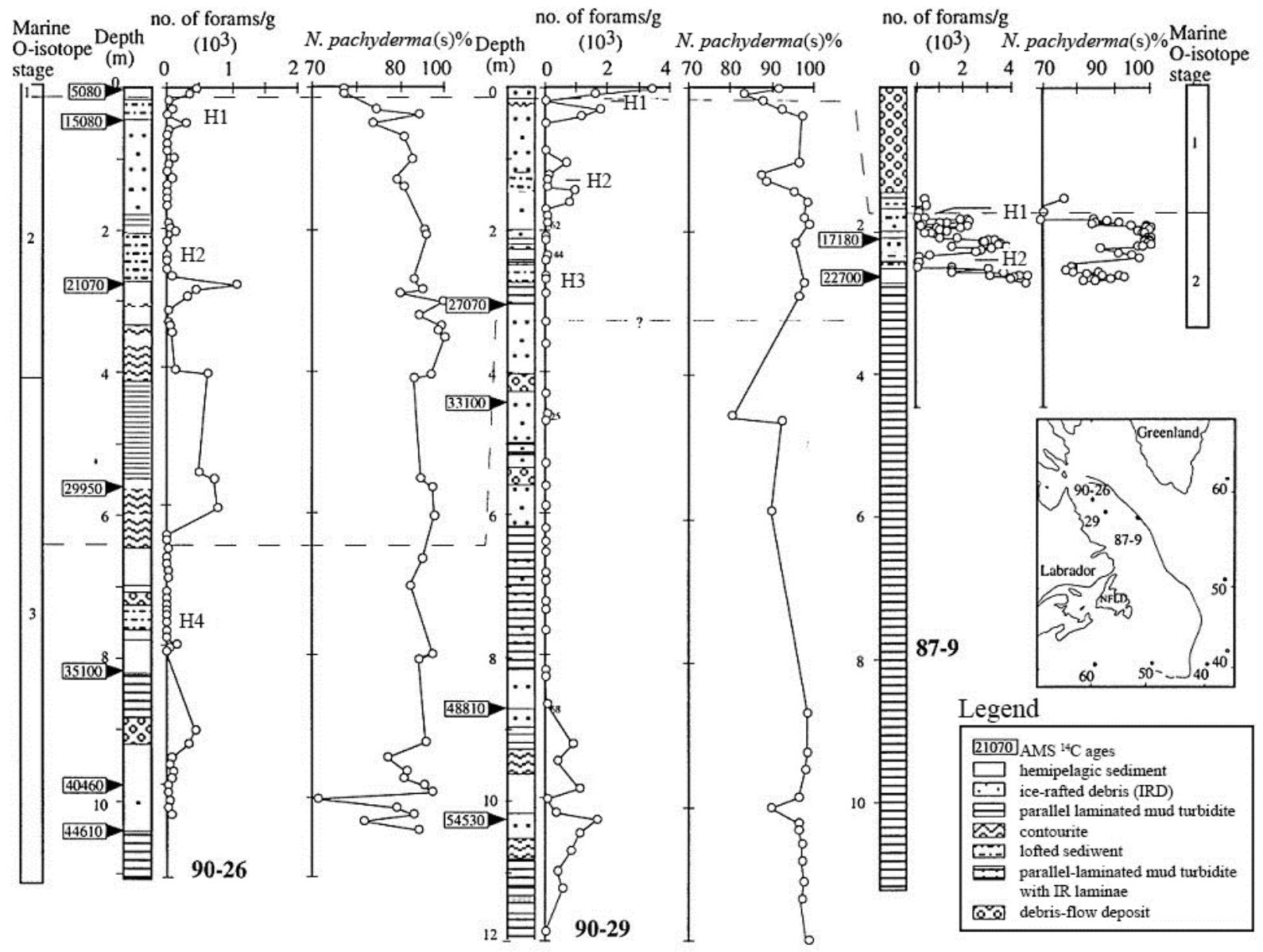




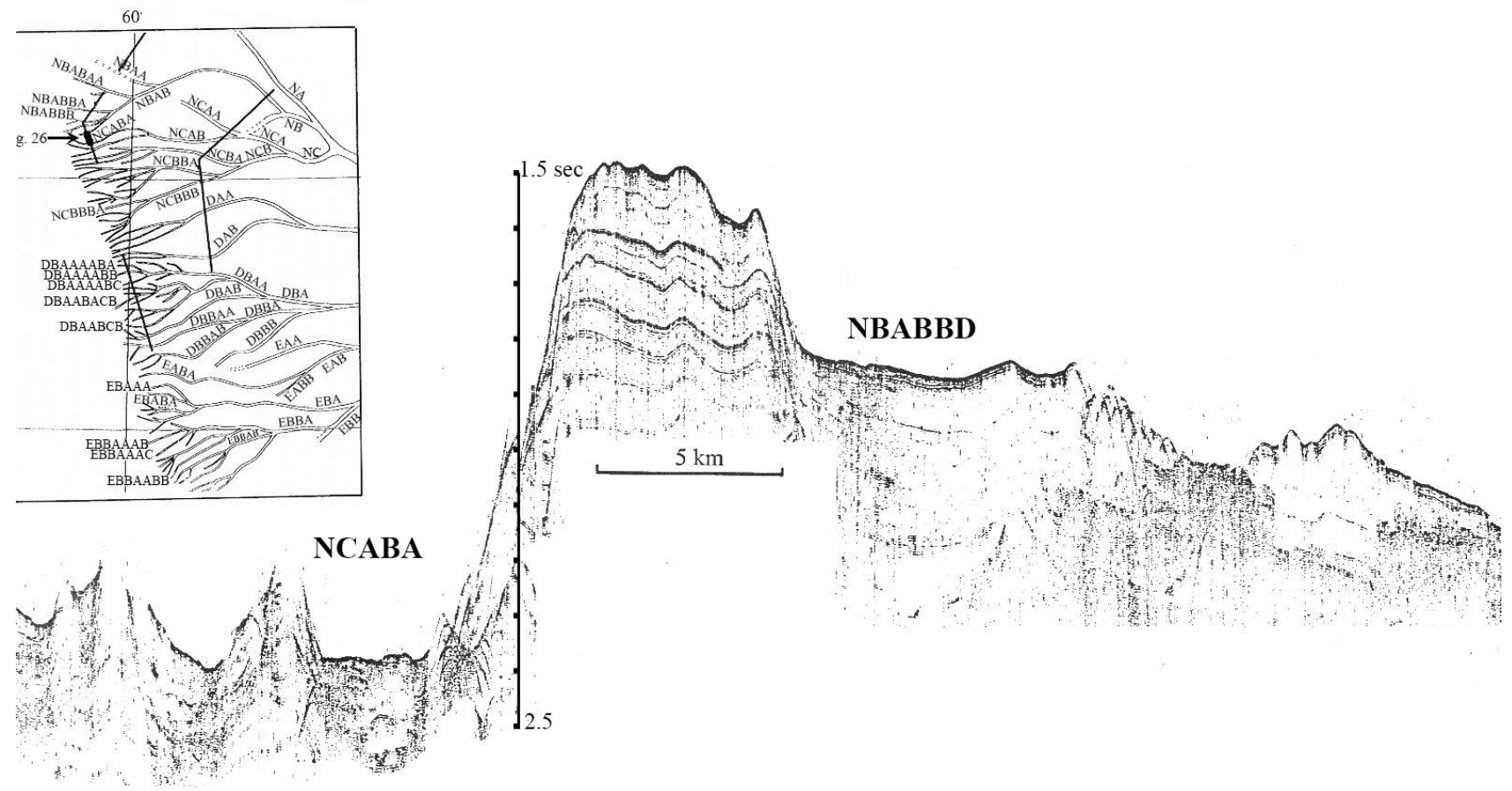

Fig 19 


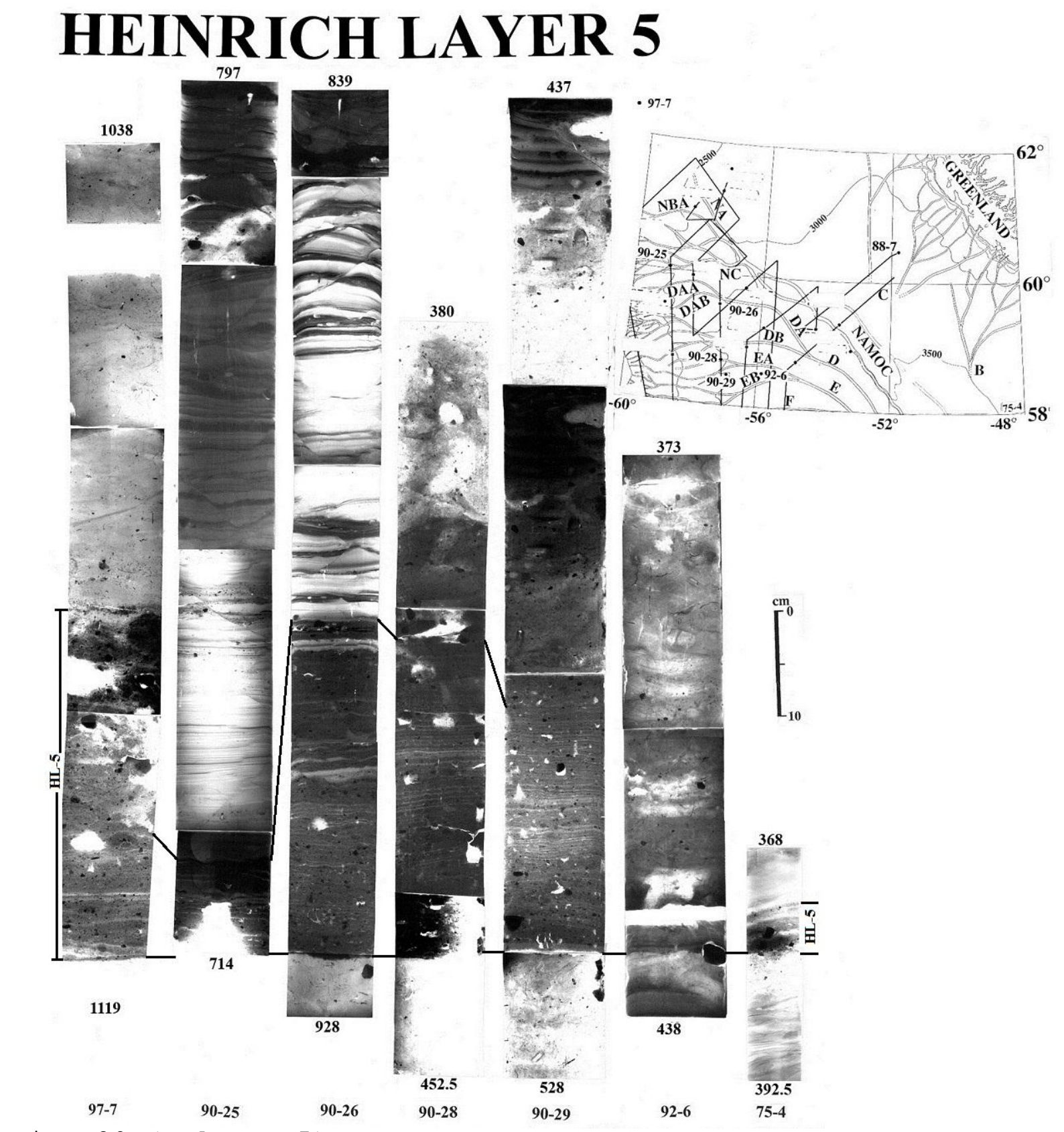

Fig. 20 (H-layer 5) 


\section{HEINRICH LAYER 5a}

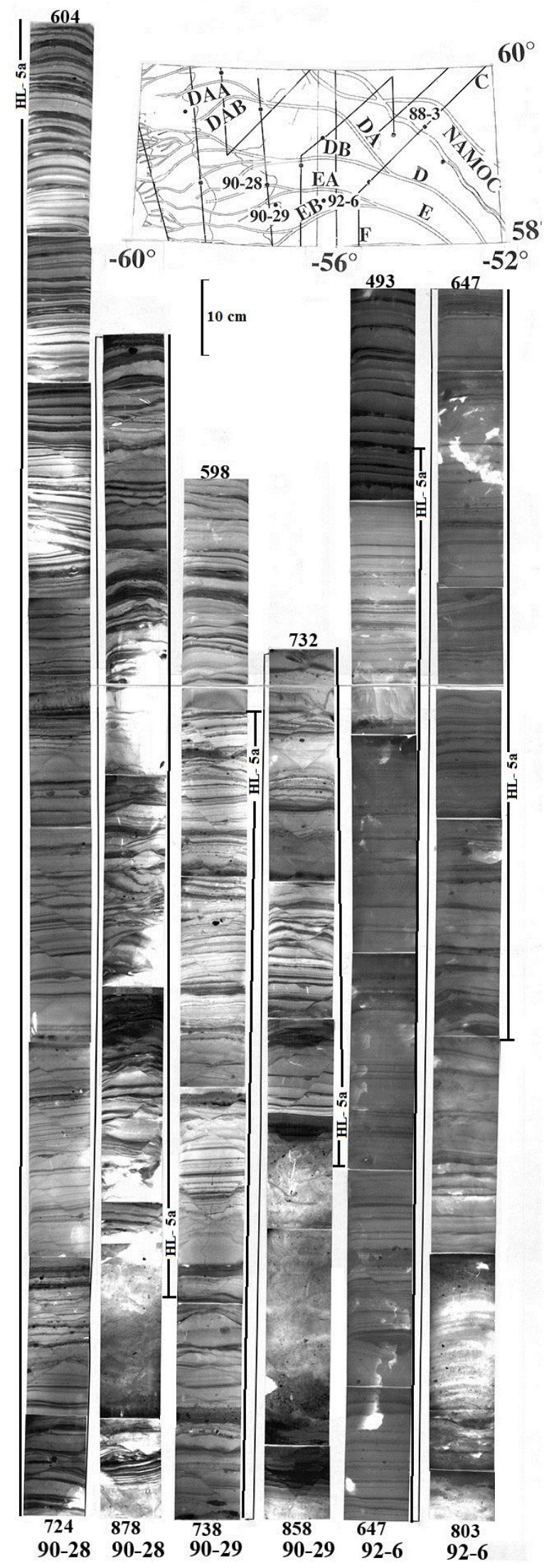


Fig. 21 (H5a)

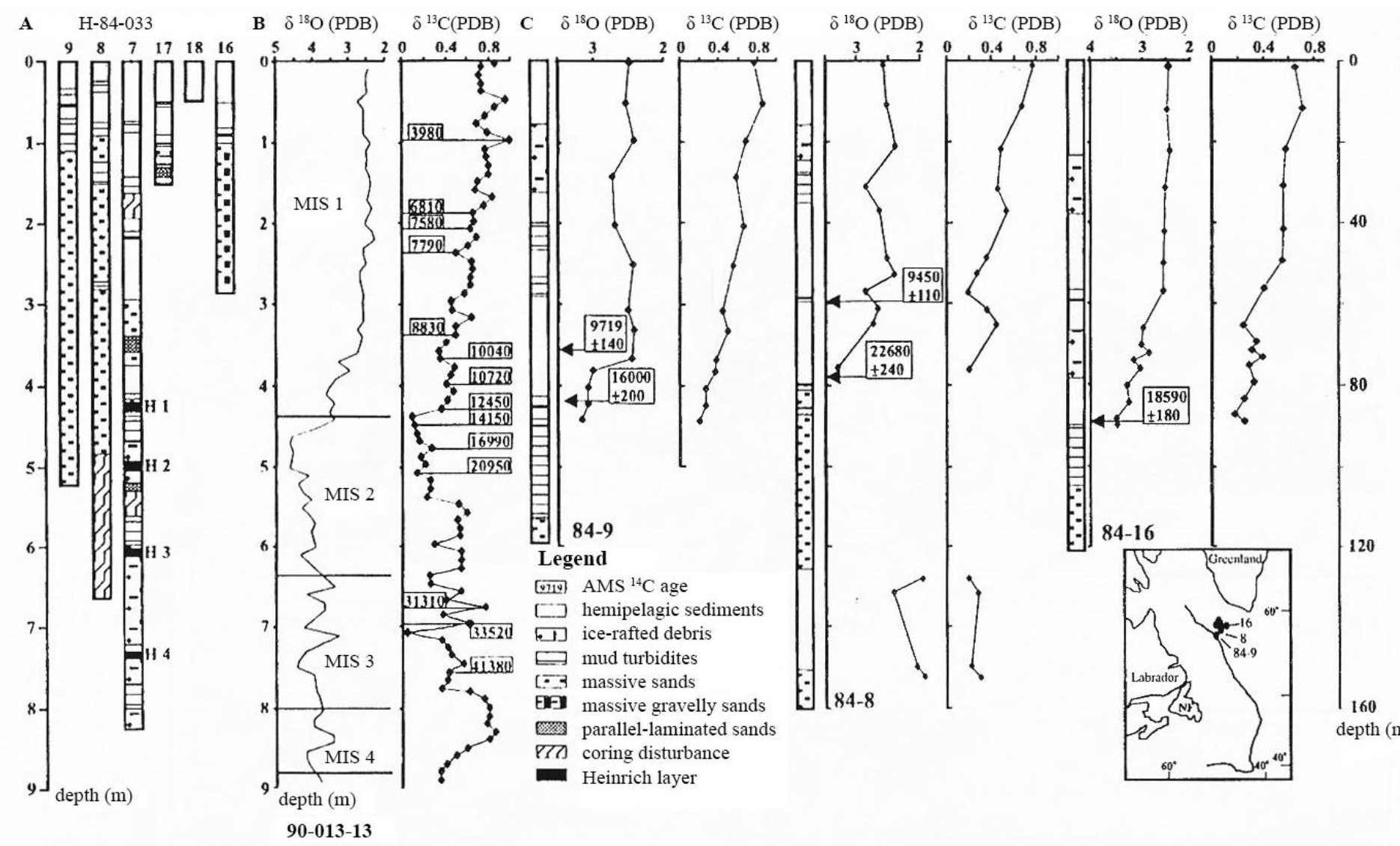

Fig. 22 
Table 1. Ages of Heinrich layers in North Atlantic and Labrador Sea cores ${ }^{\mathrm{a}}$

\begin{tabular}{|c|c|c|c|c|c|c|c|}
\hline $\begin{array}{l}\text { Heinrich } \\
\text { Event }\end{array}$ & $\begin{array}{l}\text { Bond et al. } \\
(1993)^{b}\end{array}$ & $\begin{array}{l}\text { Grousset et } \\
\text { al. }(1993)^{\mathrm{b}}\end{array}$ & $\begin{array}{l}\text { Manighetti } \\
\text { et al. } \\
(1995)^{b}\end{array}$ & $\begin{array}{l}\text { Andrews } \\
\text { et al. } \\
\text { (1998) }\end{array}$ & $\begin{array}{l}\text { Cortijo et } \\
\text { al. } \\
\text { (1997) }\end{array}$ & $\begin{array}{l}\text { van Kreveld } \\
\text { et al. }(2000)^{\mathrm{c}}\end{array}$ & $\begin{array}{l}\text { Rashid et al. } \\
(2003 b)^{d}\end{array}$ \\
\hline Core ID & $\begin{array}{l}\text { DSDP site } \\
609\end{array}$ & SU90-08 & BOFS 5K & HU87-009 & SU90-08 & SO82-05 & $\begin{array}{l}\text { HU90-013-28, -29; } \\
\text { MD95-22 (averaged) }\end{array}$ \\
\hline Location & $\begin{array}{l}49.53^{\circ} \mathrm{N} \\
24.14^{\circ} \mathrm{W}\end{array}$ & $\begin{array}{l}43.30^{\circ} \mathrm{N} \\
30.24^{\circ} \mathrm{W}\end{array}$ & $\begin{array}{l}50.41^{\circ} \mathrm{N} \\
21.52^{\circ} \mathrm{W}\end{array}$ & $\begin{array}{l}62^{\circ} 30.99 \mathrm{~N} \\
59^{\circ} 26.82 \\
\text { W }\end{array}$ & $\begin{array}{l}43.30^{\circ} \mathrm{N} \\
30.24^{\circ} \mathrm{W}\end{array}$ & $59^{\circ} \mathrm{N} 31^{\circ} \mathrm{W}$ & $\begin{array}{l}50^{\circ} 34.38 \mathrm{~N}(\mathrm{MD} 95-22) \\
43^{\circ} 03.51 \mathrm{~W}\end{array}$ \\
\hline $\mathrm{HO}$ & & & & & & & $<11.12$ \\
\hline H1 & $14-15$ & 14.50 & 14.65 & $\begin{array}{l}14.080 \\
\text { (base) }\end{array}$ & $\begin{array}{l}12.8- \\
14.7\end{array}$ & & $<17.60$ \\
\hline $\mathrm{H} 2$ & $\begin{array}{l}20.37- \\
21.77\end{array}$ & 20 & 21.578 & $\begin{array}{l}19.88- \\
20.17\end{array}$ & $\begin{array}{l}20.5- \\
22.6\end{array}$ & $23.5-24.5$ & $\sim 24.50$ \\
\hline $\mathrm{H} 3$ & 27 & 27 & 27.622 & & $26-28$ & $29.2-30$ & $\sim 31.30$ \\
\hline $\mathrm{H} 4$ & $35.50^{\mathrm{b}}$ & $38^{\mathrm{b}}$ & $39.129^{\mathrm{b}}$ & $\begin{array}{l}33.110 \\
\text { (top) }\end{array}$ & $\begin{array}{l}34- \\
35.73\end{array}$ & $38.45-39.40$ & 39.40 \\
\hline H5 & $50^{\mathrm{b}}$ & $52^{\mathrm{b}}$ & $54.70^{\mathrm{b}}$ & & $\begin{array}{l}42.8- \\
44.6\end{array}$ & $45.45-45.75$ & $\sim 46$ \\
\hline $\begin{array}{l}\text { H5a } \\
\text { H6 }\end{array}$ & $66^{\mathrm{b}}$ & $67^{\mathrm{b}}$ & $69^{\mathrm{b}}$ & & & $52-52.23(\mathrm{H} 5.2)$ & $\begin{array}{l}52-53 \\
\sim 59-60\end{array}$ \\
\hline
\end{tabular}

${ }^{\text {a }}$ Radiocarbon ages are in uncalibrated $\mathrm{ka}{ }^{14} \mathrm{C}$ years except $7^{\text {th }}$ and $8^{\text {th }}$ columns.

${ }^{\mathrm{b}}$ Older ages were interpolated by using the curve of Martinson et al. (1987).

${ }^{\mathrm{c}}$ Ages are calibrated to calendar years BP where present is set at 1950.

${ }^{\mathrm{d}}$ Calibrated (approximate) radiocarbon ages in calendar years BP where present is set at 1950. 
Table 2. Chemical composition of ash fragments

\begin{tabular}{|r|r|r|r|r|r|r|r|r|r|}
\hline & \multicolumn{1}{|c|}{ Chemical composition } \\
\hline Ash type & $\%$ Na2o & $\%$ Mgo & \%Al2o3 & $\%$ sio2 & $\%$ k2o & $\%$ CaO & $\%$ TiO2 & $\%$ Feo & $\mathrm{n}$ \\
\hline Rhyolithic & 1.11 & 0.02 & 8.73 & 64.34 & 6.15 & 2.70 & 0.46 & 8.52 & 35 \\
\hline basaltic & 0.92 & 1.65 & 7.87 & 38.87 & 1.09 & 13.12 & 4.52 & 24.10 & 51 \\
\hline
\end{tabular}

Table 3. Carbonate concentration in coarse and fine fractions of Heinrich layer types. Data for type II from cores 90-26 and 92-5; type III, core 90-34, type IV, Core 87-9 and type V, cores 88-1 , 88-7 and 90-29 trigger -weight core.

\begin{tabular}{|l|l|l|l|l|}
\hline $\mathrm{HL}$ type & $\mathrm{CaCO}_{3} \%$ & $<63 \mu m$ & $>6 \mathbf{3} \mu m$ & $\mathrm{n}$ \\
\hline Type II(lofted sediment) & 40.4 & 98.4 & 1.6 & 12 \\
\hline Type II1 (ice - rafted) & 39.3 & 89.6 & 10.4 & 13 \\
\hline Type III & 31.6 & 91.4 & 8.6 & 7 \\
\hline Type IV (mud turbidite) & 34.2 & 97.7 & 2.3 & 2 \\
\hline Type IV1 (ice - rafted) & 40.8 & 85.8 & 14.2 & 4 \\
\hline Type V & 32.6 & 82.4 & 17.6 & 6 \\
\hline
\end{tabular}

Table 4. Sediment distribution in modern icebergs

\begin{tabular}{|r|r|r|r|r|}
\hline & \multicolumn{3}{|c|}{ Sediment concentration of sediment-rich zone (\%) } \\
\hline Locality & $<63 \mu m$ & $>63 \mu m$ & Reference & $\mathrm{n}$ \\
\hline Antarctic & 41.9 & 58.1 & Anderson et al. (1980) & 7 \\
\hline Spitsbergen & 41.5 & 58.5 & Dowdeswell and Dowdeswell (1989) & 2 \\
\hline Alaska & 30.9 & 69.1 & Hoskin and Valencia (1976) & 9 \\
\hline Average & 36.4 & 63.6 & & \\
\hline
\end{tabular}

